\title{
The 1960s Drought and the Subsequent Shift to a Wetter Climate in the Catskill Mountains Region of the New York City Watershed*
}

\author{
Richard Seager, Neil Pederson, Yochanan Kushnir, and Jennifer NaKamura \\ Lamont-Doherty Earth Observatory, Columbia University, Palisades, New York \\ STEPHANIE JURBURG \\ Columbia College, New York, New York
}

(Manuscript received 13 September 2011, in final form 3 April 2012)

\begin{abstract}
The precipitation history over the last century in the Catskill Mountains region that supplies water to New York City is studied. A severe drought occurred in the early to mid-1960s followed by a wet period that continues. Interannual variability of precipitation in the region is related to patterns of atmospheric circulation variability in the midlatitude east Pacific-North America-west Atlantic sector with no link to the tropics. Associated SST variations in the Atlantic are consistent with being forced by the anomalous atmospheric flow rather than being causal. In winter and spring the 1960s drought was associated with a low pressure anomaly over the midlatitude North Atlantic Ocean and northerly subsiding flow over the greater Catskills region that would likely suppress precipitation. The cold SSTs offshore during the drought are consistent with atmospheric forcing of the ocean. The subsequent wet period was associated with high pressure anomalies over the Atlantic Ocean and ascending southerly flow over eastern North America favoring increased precipitation and a strengthening of the Northern Hemisphere storm track. Neither the drought nor the subsequent pluvial are simulated in sea surface temperature-forced atmosphere GCMs. The long-term wetting is also not simulated as a response to changes in radiative forcing by coupled models. It is concluded that past precipitation variability in the region, including the drought and pluvial, were most likely caused by internal atmospheric variability. Such events are unpredictable and a drought like the 1960s one could return while the long-term wetting trend need not continue-conclusions that have implications for management of New York City's water resources.
\end{abstract}

\section{Introduction}

New York City's Department of Environmental Protection delivers 3.8 billion liters of water a day to 9 million customers from a network of upstate reservoirs connected to the city by underground aqueducts. New York City's water supply system began to be developed in the mid-nineteenth century, first with the damming of the Croton River in Westchester County about $50 \mathrm{~km}$ north of the city and the opening in 1842 of the Croton

* Lamont-Doherty Earth Observatory Contribution Number 7555 .

Corresponding author address: Richard Seager, Lamont-Doherty Earth Observatory of Columbia University, 61 Route 9W, Palisades, NY 10964.

E-mail: seager@ldeo.columbia.edu
Aqueduct that carries the water to Manhattan via the spectacular Highbridge Aqueduct across the Harlem River. By the late nineteenth century, growth of the city made the Croton supply inadequate and the city's Board of Water Supply began to develop additional water supply in the eastern part of the Catskill Mountains, $160 \mathrm{~km}$ north of the city. This phase was completed in 1928 and includes the Catskill Aqueduct flowing from the mountains and syphoned under the Hudson River toward the Croton supply system. The combined Croton and Catskill supply soon proved itself inadequate to keep up with the city's growth and from the 1930s to the 1960s the city built reservoirs in the western parts of the Catskills capturing water bound for the Delaware River and diverting the water to the city via the Delaware Aqueduct. The city's water supply was completed in 1964 and has not been expanded since (Bone et al. 2006). 
The Croton watershed is heavily populated and, hence, its water must be filtered before use. The Catskills watershed is, in contrast, mostly forest and farmland; water from it is not filtered other than by natural processes. In recent decades the city has expended considerable effort to maintain the quality of the Catskill water supply and, hence, avoid the need to build an expensive filtration plant. This has not been simple as the majority of the land in the watershed is privately owned. Consequently, the city has pursued a multipronged method involving seller-willing acquisition of land in the watershed, the creation of conservation easements where development rights on private land are purchased by the city and the land preserved, rental payments to farmers who create setbacks and buffer zones between watercourses and sources of agricultural pollutants, and the creation of nonprofit land trusts to set aside open space for public access, preservation, agriculture, and other uses that pose no threat to the quality of the water supply (Pires 2004). To date, this approach has been successful in maintaining water quality and the U.S. Environmental Protection Agency awarded the city a new 10-yr Filtration Avoidance Determination in 2007. Indeed, New York City's naturally filtered Catskill water supply system is considered one of the leading examples in the world of the natural capital provided by a well-managed ecosystem (Postel and Thompson 2005; Turner and Daily 2008).

Despite these successes the New York City water supply system does face some problems (see Rosenzweig et al. 2007 for a discussion of the city's efforts to plan for expected climate changes). An increase in precipitation intensity, which is widespread across the United States (Groisman et al. 2005), has led to increases in flux of organic matter into Catskill reservoirs necessitating addition of aluminum sulfate to reservoirs to encourage sedimentation and the possible raising of levels from which water is removed from reservoirs before being passed down the supply system (New York Times, 20 July 2006, and see http://www.amwa.net/cs/climatechange/ newyorkcity). Also, rising temperatures (Trombulak and Wolfson 2004) are causing increasing evaporative demand, decreases in winter snowpacks, and earlier snowmelt (Burns et al. 2007; Hayhoe et al. 2007; see also Huntington et al. 2004 for the case of New England), posing problems for the water supply system. However, the northeastern United States is fortunate in that, since widespread record keeping began, it has not experienced the succession of multiyear devastating droughts that have afflicted the southwestern United States and Great Plains, largely because of the weaker influence of tropical sea surface temperature variations on precipitation in the Northeast than in those more western regions (e.g., Seager et al. 2005b). Model projections of the future suggest that the watershed will experience more short-term droughts as a consequence of warming and increasing evaporative demand but no increase in the frequency of multiyear droughts while the mean precipitation slightly increases (Hayhoe et al. 2007).

The most recent drought was from about 1998 to 2002 and was the eastern extension of a continental-scale drought (Seager 2007) that was extremely serious in the west but also greatly stressed water resources in the east (Lyon et al. 2005). However, the "drought of record" is one that extended from 1962 to 1966. This drought has received some attention (Namias 1966, 1983) but not in the recent period of atmospheric reanalyses and extensive simulations with climate models. Its character, causes, and potential predictability are largely unknown. However, a drought reconstruction based on four tree ring chronologies from the Shawangunk Mountains and another from Schunemunk Mountain, all just south of the Catskills, shows the 1960s drought to have been the most severe in the last few centuries although longer, but less extreme, droughts had occurred in prior centuries (Cook and Jacoby 1977). Later analyses that used continental tree ring networks to create a gridded analysis also highlighted the 1960s drought as quite unusual (Cook et al. 1999). Similar conclusions were reached by Lyon et al. (2005) examining the specific case of Rockland County in southeastern New York. A recent analysis by one of us includes the Cook and Jacoby data but increases the total number of chronologies by severalfold and covers a much larger area of the Hudson Valley and greater Catskills regions and shows the 1960s drought to be a severe interruption of a general wetting trend over the past half millennium (Pederson et al. 2012, manuscript submitted to J. Climate). Just as curious as the 1960s drought is the shift to a wetter climate in the region that began around the early 1970s and has continued to date. The causes of this are unknown.

The direct economic consequences of Northeast droughts are quite modest and limited to operations like golf courses, car washes, etc., and there can even be benefits such as increased yields of tomatoes benefitting from abundant sun (Degaetano 1999). However, the sustainability of the New York City water supply system is of tremendous economic value since the costs of filtration plants are large and enhancements to the system in terms of increased storage seem essentially out of the question. In this regard it is notable that the water supply system was completed during the 1960s drought and since then the system has been exposed to a rather wet climate with only a few short and not-too-severe disruptions. The city has also moved to greatly reduce 
water consumption in recent decades but the supply system would be greatly stressed if a 1960s style drought returned. Indeed, is the recent wetting a result of secular climate change and can be expected to continue or is it a result of climate variability and at some point we can expect the climate to revert to the drier pre-1970s conditions? Further, what are the dynamical causes of the 1960s drought and subsequent wet conditions? Are they related to SST changes and hence could potentially be predicted if the slowly evolving SSTs could be predicted or are they the result of internal unpredictable atmospheric variability? Here we attempt to answer these questions.

\section{Observational and model data}

The precipitation data used is from the Global Precipitation Climatology Centre (GPCC; Schneider et al. 2008) and is gridded and covers 1901 to 2007. We also analyzed precipitation data from weather stations reported in the Global Historical Climatology Network (GHCN) dataset (http://iridl.ldeo.columbia.edu/SOURCES/.NOAA/ .NCDC/.GHCN/.v2beta/.prcp/). To examine circulation we use the National Centers for Environmental PredictionNational Center for Atmospheric Research (NCEPNCAR) reanalysis covering 1949-present (Kalnay et al. 1996; Kistler et al. 2001) and the Twentieth Century Reanalysis (20CR), which only assimilates surface pressure data but covers 1870-2008 (Compo et al. 2011). For sea surface temperature we use the Hadley Center Sea Ice and Sea Surface Temperature analysis (HadISST) (Rayner et al. 2003).

To examine if the 1960s drought and subsequent wetting can be reproduced as an atmospheric response to global SST variations we have examined a number of ensemble simulations with atmospheric general circulation models (GCMs) forced by historical SSTs. These include three models developed by NCAR, the Community Climate Model 3 [CCM3, which has been used extensively by us for North American drought research (e.g., Seager et al. 2005b)], and Community Atmosphere Models 3.5 and 4. The NCAR models were all run at Lamont and cover 1856-2010 with 16-member ensembles beginning with different initial conditions on 1 January 1856. In addition, we make use of four shorterperiod ensembles with other models for which the data are available from the International Research Institute for Climate and Society Data Library (http://iridl.ldeo. columbia.edu/docfind/databrief/cat-sim.html). These are the National Aeronautics and Space Administration (NASA) Seasonal to Interannual Prediction Program (NSIPP) model (Schubert et al. 2004a), the Geophysical Fluid Dynamics Laboratory (GFDL) Atmosphere Model
2.1 (AM2.1; Delworth et al. 2006), the Center for OceanLand-Atmosphere Studies (COLA; Kirtman et al. 2002), and the European Centre Hamburg Model 4.5 (ECHAM4.5; Roeckner et al. 1996).

To look for any anthropogenic influence on precipitation in the region we examined the twentieth-century simulations from the 24 coupled atmosphere-ocean models participating in the Coupled Model Intercomparison Project 3 (CMIP3; Meehl et al. 2007) and that were assessed in the Intergovernmental Panel on Climate Change (IPCC) Fourth Assessment Report (AR4; Houghton et al. 2007). These simulations were forced by known and estimated changes in trace gases, solar irradiance, volcanism, aerosols, and land use, with differences between models as to how and which forcings were included.

It was hoped that we would be able to use the NCEP reanalysis to examine the moisture budget during the 1960s drought and subsequent wet period to determine the changes in water vapor transport by the mean and transient flow that sustained the $P-E$ anomalies and to relate these to the circulation anomalies. In prior work, for example, we have done this successfully for El NiñoSouthern Oscillation-related precipitation variability over North America (Seager et al. 2005a). As in that work, we calculated the NCEP-derived $P$ as the sum of the NCEP $E$ and the vertically integrated moisture convergence by the mean plus transient flow. The derived $P$ does not capture the 1960s drought well (especially during the critical spring season) and also does not reproduce the observed increase of $P$ along the east coast of the United States after the 1960s. We have also found that the NCEP moisture budget did not capture the southwest drought of 1998-2004 (Seager 2007) so this came as no surprise. Hence we do not examine the NCEP moisture budget in an attempt to determine how moisture transports varied to generate these phenomena. Apparently the quality of the data and the assimilation scheme used within the NCEP reanalysis is sufficient to capture the moisture budget anomalies associated with ENSO, the dominant global source of seasonal-to-interannual hydroclimate anomalies, but not sufficient to capture smaller amplitude, but sustained, anomalies associated with major droughts and pluvials.

\section{History of observed precipitation in the Catskill Mountains region of the northeastern United States}

We define an area that includes the Catskill Mountains but since, first, the number of stations in the Catskills is very small and, second, the precipitation anomalies that impact the Catskills extend beyond the Mountains themselves, it also includes a much larger area of New 


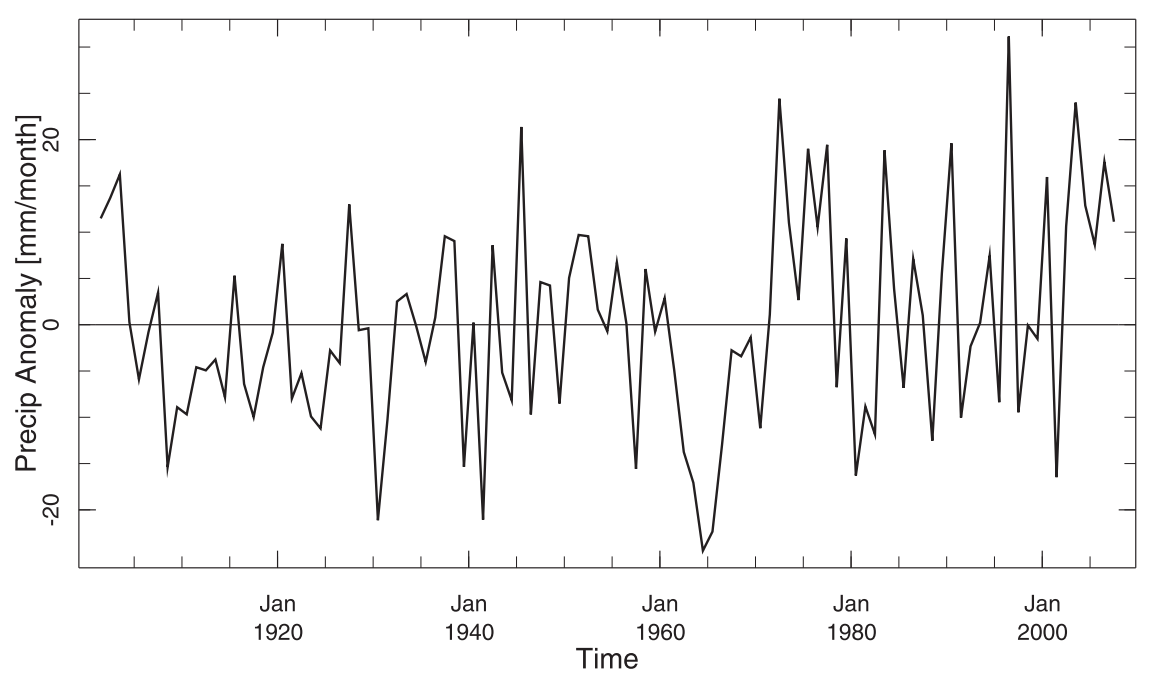

FIG. 1. The annual mean precipitation anomaly relative to the long-term mean for the Catskill Mountains and surrounding areas $\left(41^{\circ}-43^{\circ} \mathrm{N}, 76^{\circ}-73.5^{\circ} \mathrm{W}\right)$ from the GPCC gridded data. Units are mm month ${ }^{-1}$.

York, Pennsylvania, and New Jersey. It is bounded by $41^{\circ}$ and $43^{\circ} \mathrm{N}$ and $76^{\circ}$ and $73.5^{\circ} \mathrm{W}$. We refer to this as the greater Catskills area. Figure 1 shows the time series of annual mean precipitation averaged over this area in the gridded GPCC dataset. The striking features are the early to mid-1960s drought and the overwhelmingly wet period from the early 1970s until the end of the record. The longterm annual mean precipitation in this region is about $92 \mathrm{~mm} \mathrm{month}^{-1}$ so the 1960s drought represented about a $20 \%$ drop in total precipitation for a few years. Precipitation values by season for the climatology, the drought, and the subsequent wet period and the 19012007 trend are shown in Table 1.

Figure 2 shows seasonal time series of the Catskills region's precipitation. The 1960s drought appears as a year-round event but with weakest expression in the winter December-February (DJF) season. The post1960s pluvial is a phenomenon of the spring MarchMay (MAM) and fall September-November (SON) seasons. A century-long wetting trend is most obvious in fall.
To assess how variable in space the drought and subsequent pluvial were, in Fig. 3 we show time series of precipitation from 23 weather stations from the GHCN database that are in the greater Catskills region together with a map showing their location. The 1960s drought is a ubiquitous feature in this station data. The post-1960s pluvial also appears in almost all the station data, although in some there is evidence of a wet period in the earlier part of the twentieth century too (such as Port Jervis, Yorktown Heights, and Cooperstown) while in others it is the tail end of a century-long wetting trend (such as Albany, Montrose, Binghamton, and West Point). The average of the station records is also shown and agrees with the spatial average of the gridded GPCC data shown in Fig. 1.

\section{Association of Catskills region precipitation with large-scale atmospheric and oceanic conditions}

It is normal in studies like this to examine the spatial relationships between time series of the phenomenon

TABLE 1. The climatological precipitation and totals during the 1960s drought and subsequent pluvial, in mm month ${ }^{-1}$, and the linear least squares trend over 1901-2007, in $\mathrm{mm}$ month $^{-1}(107 \mathrm{yr})^{-1}$, all by season for the greater Catskills region using GPCC data.

\begin{tabular}{lcccc}
\hline \hline Season & $\begin{array}{c}\text { Climatology } \\
\mathrm{mm} \mathrm{month}^{-1}\end{array}$ & $\begin{array}{c}\text { 1962-66 drought } \\
\mathrm{mm} \mathrm{month}^{-1}\end{array}$ & $\begin{array}{c}\text { 1972-2007 pluvial } \\
\mathrm{mm} \mathrm{month}^{-1}\end{array}$ & $\begin{array}{c}\text { Trend mm month } \\
\left(107 \mathrm{yr}^{-1}\right.\end{array}$ \\
\hline DJF & 78 & 72 & 79 & -3.2 \\
MAM & 92 & 70 & 97 & 10.4 \\
JJA & 103 & 74 & 106 & -1.8 \\
SON & 94 & 78 & 103 & 21.4 \\
\hline
\end{tabular}




\section{Seasonal Precipitation Anomaly over Catskill Mountains}

a) DJF

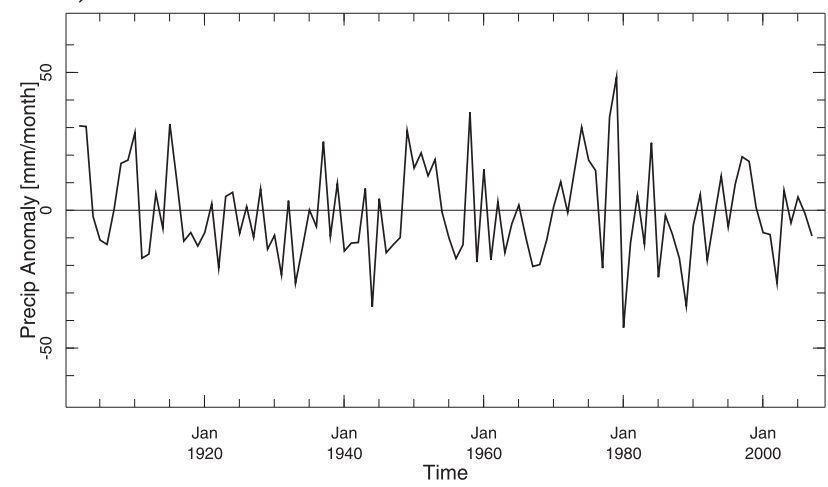

c) JJA

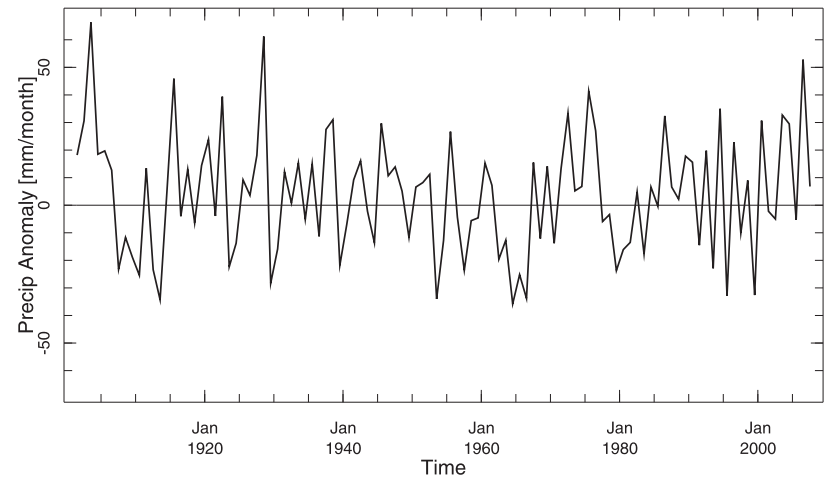

b) MAM

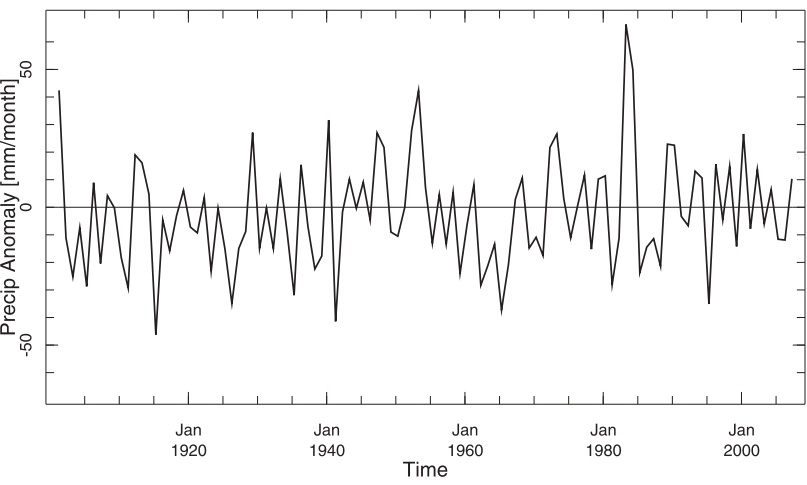

d) $\mathrm{SON}$

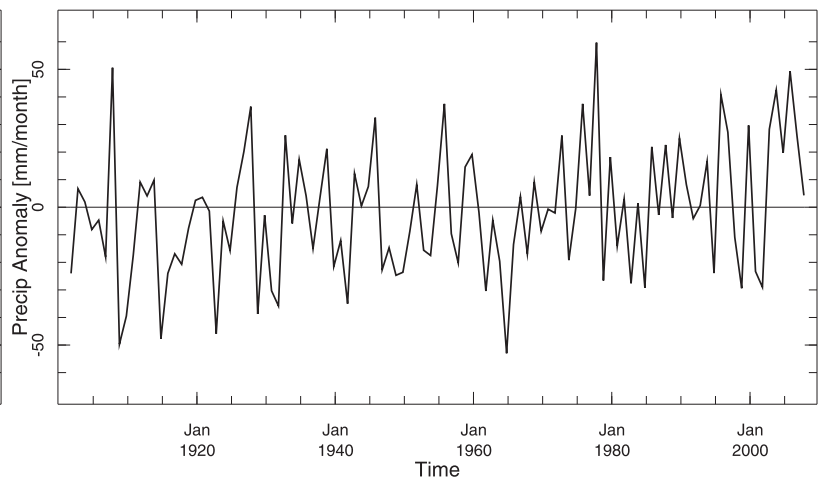

FIG. 2. The seasonal mean (DJF, MAM, JJA, and SON) precipitation anomalies relative to the long-term seasonal means for the Catskill Mountains and surrounding areas from the GPCC gridded data. Units are mm month ${ }^{-1}$.

of interest, in this case precipitation in the greater Catskills region, and the large-scale atmospheric circulation and the SSTs using linear correlation and regression analyses. To begin this we first correlated the GPCC precipitation data across North America with the time series of greater Catskills region precipitation for the winter, spring, summer, and fall seasons. Results are shown in Fig. 4 and are only plotted where significant at the $5 \%$ level according to a two-sided $t$ test and after accounting for autocorrelation in the time series according to the method of Trenberth (1984). In the winter when it is wet in the Catskills region it is typically wet across eastern North America from the Gulf Coast to Nova Scotia and from the Great Plains and Great Lakes to the Atlantic Ocean. Correlations elsewhere are weak. In the summer the area of precipitation coherence is more focused on the northeastern United States and southeastern Canada but still spreads to the southeast and southern United States. Spring and fall seasons also have correlation patterns quite focused on the Northeast. Clearly for the typical cases of seasons when the greater Catskills region is drier or wetter than normal this occurs within a pattern of precipitation anomaly that includes, at most, eastern North America. In particular, there is little correlation between precipitation in the Catskill Mountains region and precipitation in the Great Plains or the Southwestthe regions of North America with striking persistent droughts forced by tropical SST anomalies (Schubert et al. 2004b,a; Seager et al. 2005b; Seager 2007). Droughts in the Northeast must be caused by different processes.

Figure 5 shows the correlation of the greater Catskillsarea precipitation with Northern Hemisphere and equatorial 500-hPa geopotential height anomalies for the 1901-2007 period using the 20CR heights and for the four seasons. During the winter a clear wave train is evident upstream and downstream of the Catskills that is at peak strength over North America. The wave train has no obvious connection to the tropics and probably 


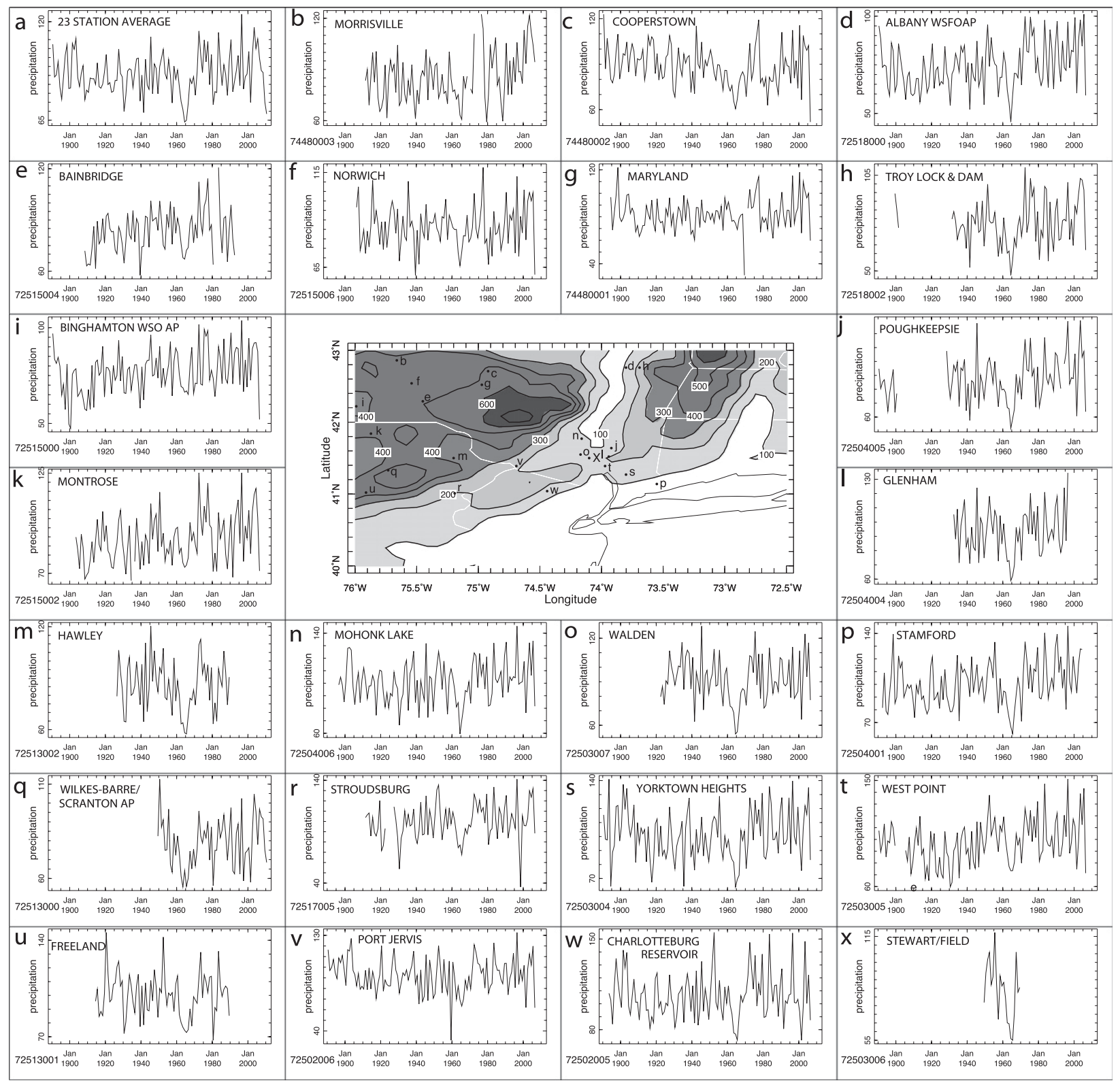

FIG. 3. Total annual mean precipitation records from weather stations contained within the greater Catskills region. Only stations within the region are plotted with locations shown on the topographic map. Station data are from the GHCN. (a) The average of the 23 stations. This can be compared to the regional average of the GPCC gridded data plotted in Figs. 1 and 2. State borders are plotted as white lines. Units are mm month ${ }^{-1}$.

originates in midlatitude atmospheric dynamical processes. During the summer the anomalous wave train also covers much of the Pacific-North America-Atlantic sector of the midlatitudes with a shorter spatial scale than in the winter. In spring and fall the wave train anomalies are rather more localized over the North AmericaAtlantic sector. In all seasons, wet in the greater Catskills region is associated with southerly midtropospheric flow that may be conducive to rising, moist air and increased precipitation.

Figure 6 extends this analysis showing the correlation patterns for SST and sea level pressure (SLP) again showing values only where significant at the $5 \%$ level after accounting for autocorrelation in the Catskills precipitation index. During the winter season, wet in the Catskills region is associated with a southwest-northeast, 


\section{Correlation of Catskill Mountain Precip on GPCC Precip}

a) DJF

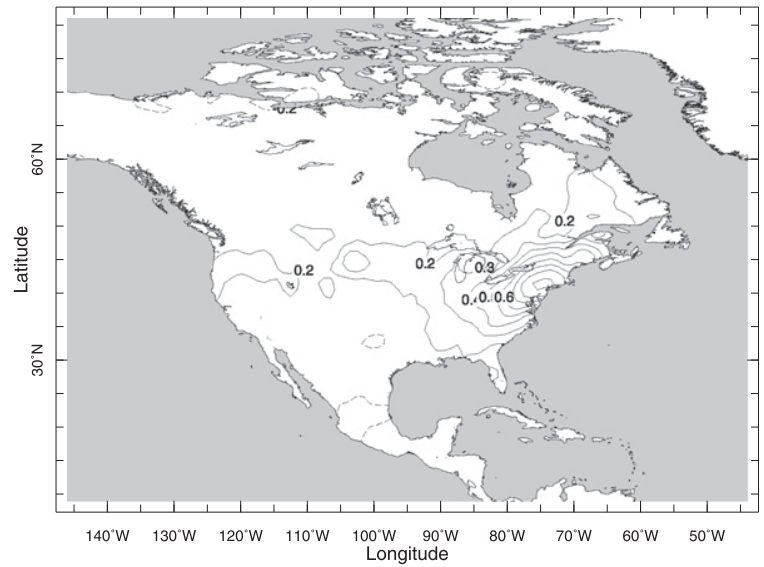

c) JJA

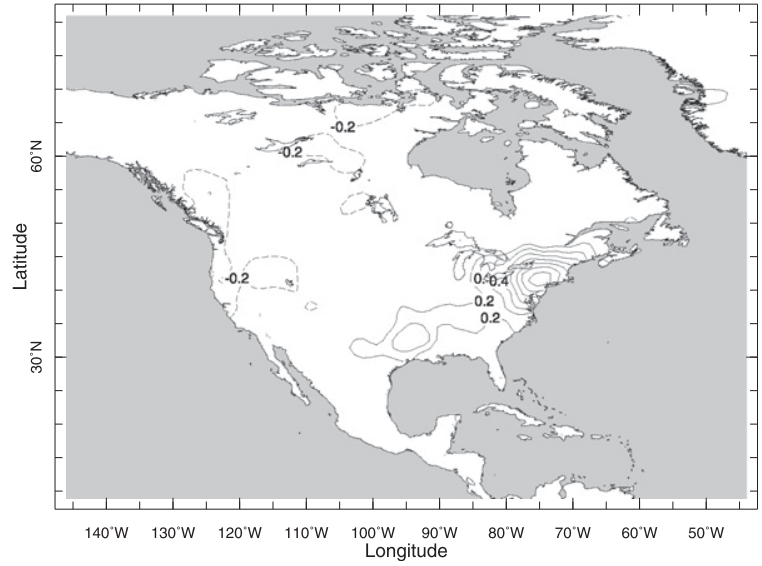

b) MAM

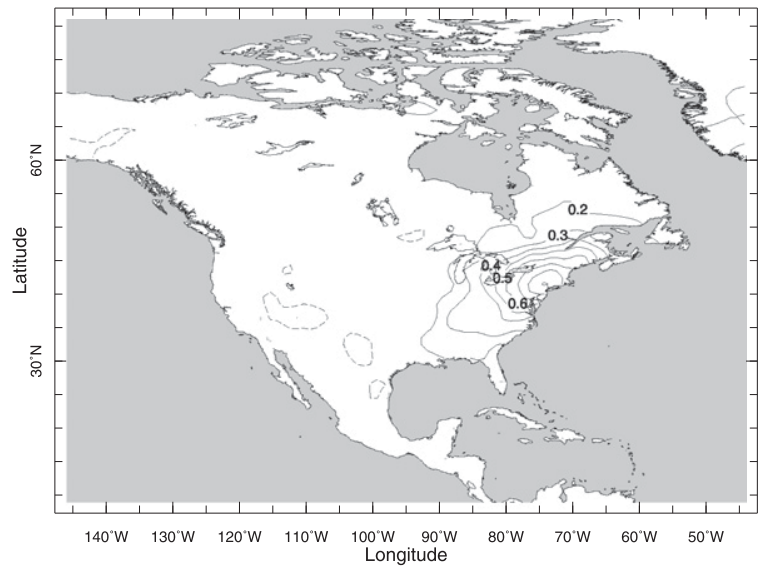

d) SON

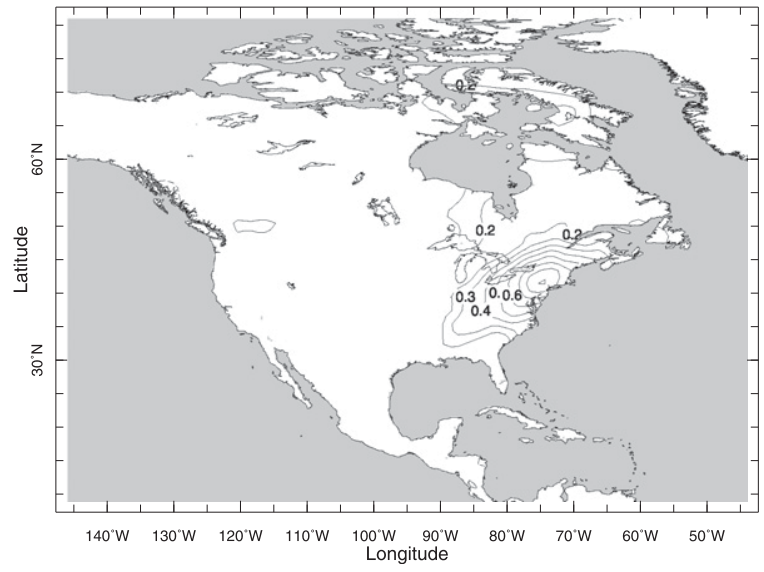

FIG. 4. The correlation between precipitation averaged over the greater Catskills region and the precipitation across North America for the DJF, MAM, JJA, and SON seasons. Accounting for autocorrelation in the precipitation time series, correlation coefficients greater than 0.2 are significant at the $5 \%$ level and the contour interval therefore begins at \pm 0.2 .

low-high dipole of SLP anomalies and onshore flow. This same SLP pattern is accentuated in spring. Few correlations with SST are statistically significant. However, by spring warm SST anomalies lie under the onshore flow with cool SST anomalies to the northeast, south of Greenland, where the flow anomaly is northwesterly. These SST anomalies are consistent with atmospheric forcing via surface heat fluxes. Onshore flow anomalies into northeast North America are actually a reduced offshore flow and hence would drive a reduction in latent and sensible heat flux cooling of coastal water by cold, dry advection. Near Greenland northerly flow anomalies would increase latent and sensible cooling by increased dry and cold advection (see Seager et al. 2000 for a detailed discussion of these mechanisms of air-sea interaction and Cayan 1992b,a for an early demonstration of the phenomena). In the summer, wet in the Catskills is associated with a high SLP anomaly immediately off the northeast United States and southeast Canada and onshore flow into the Catskills region. A small area of statistically significant warm SST anomalies is located under and east of the high, again consistent with atmospheric forcing of the ocean. The fall SLP pattern is similar to that in spring. In this case Catskills region fall precipitation is associated with widespread statistically significant warming, especially in the tropical Atlantic and Indian Oceans. This could be due to the fact that as the Catskills region has become wetter the planet 


\section{Correlation of Catskill Precip on 20CR 500 hPa Height}

a) DJF

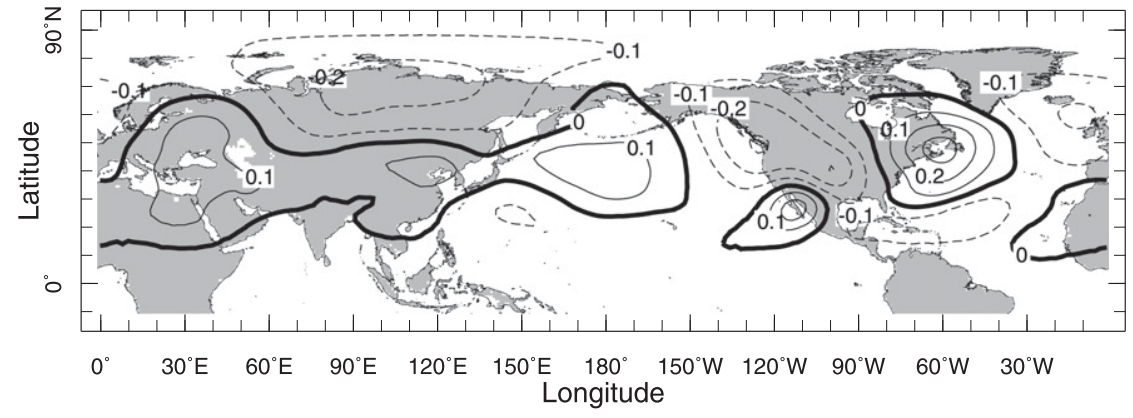

b) MAM

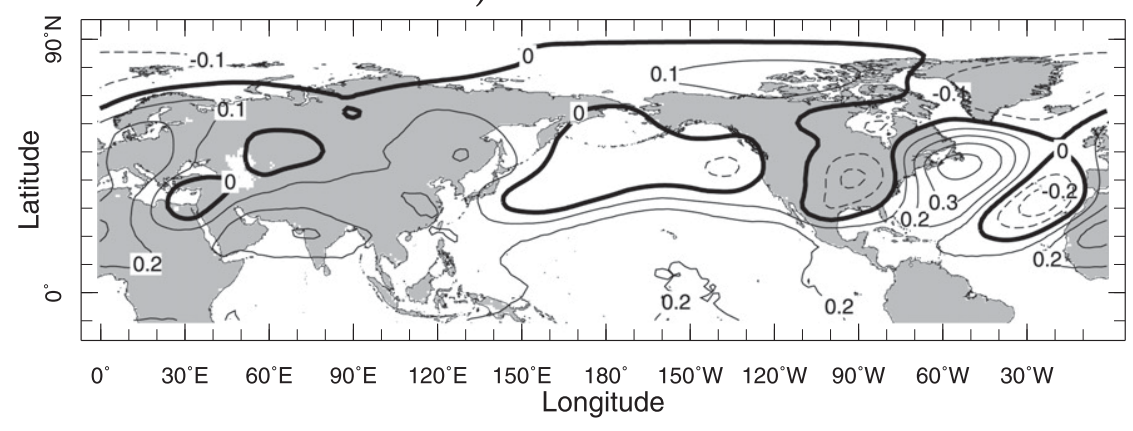

c) JJA

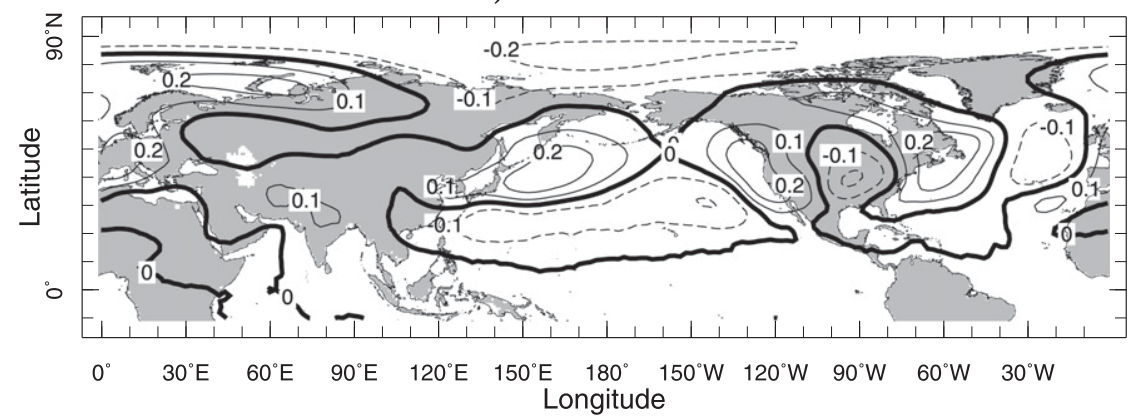

d) $\mathrm{SON}$

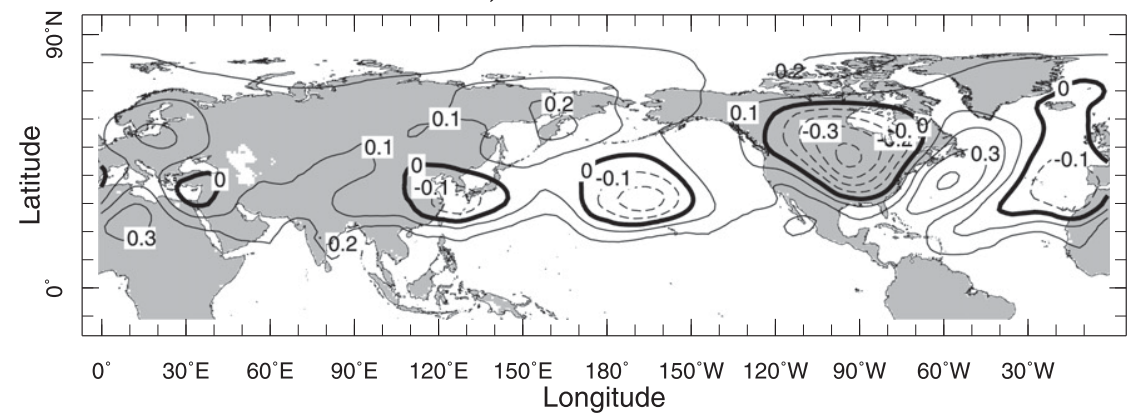

FIG. 5. The correlation between precipitation averaged over the greater Catskills region and 500-hPa geopotential heights for the (top) DJF, (upper middle) MAM, (lower middle) JJA, and (bottom) SON seasons. The geopotential heights are from the 20CR allowing correlation to be over the 1901-2007 period. 


\section{Corr Catskill P on SST (color) and SLP (contours)}

a) DJF

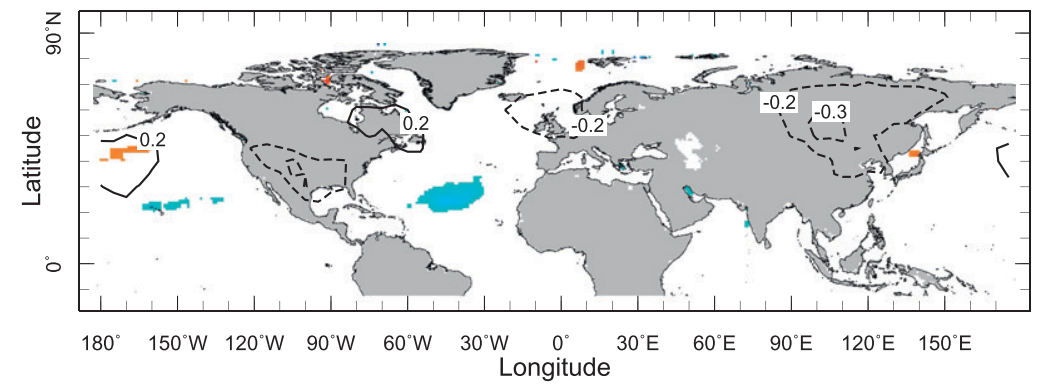

b) MAM

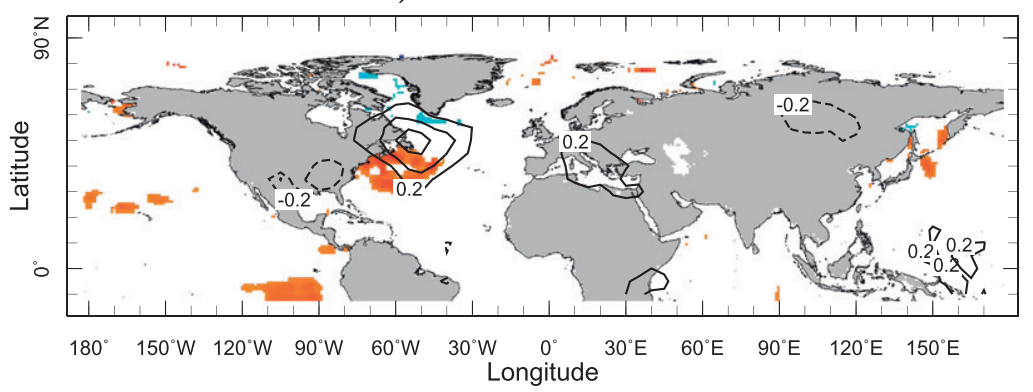

c) JJA

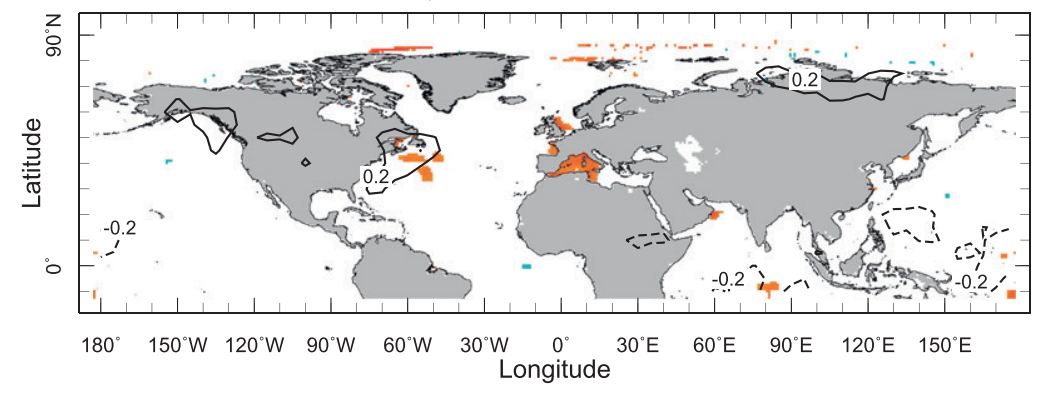

d) $\mathrm{SON}$
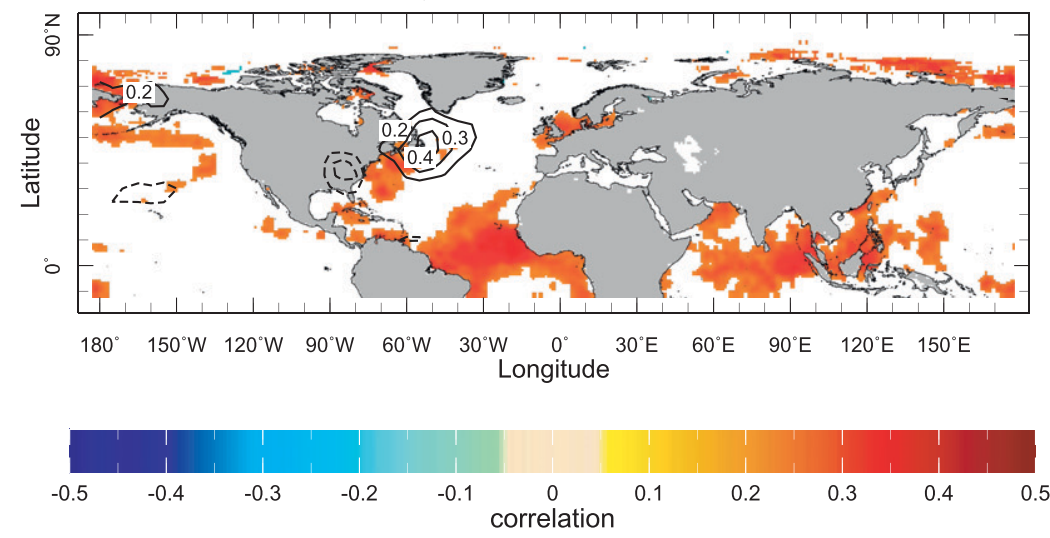

FIG. 6. The correlation between precipitation averaged over the greater Catskills region and SST and SLP for the (top) DJF, (upper middle) MAM, (lower middle) JJA, and (bottom) SON seasons. SLP data are from 20CR and correlations are over the 1901-2007 period. 
has also warmed, although there need be no causal link need between these two phenomena. We will return to this matter in section $8 .^{1}$

\section{The 1960s drought: Character and atmospheric causes}

Having determined the typical atmosphere-ocean states associated with dry and wet periods in the greater Catskills region, we now assess whether the 1960s drought was simply an unusually long period of a normal dryinducing atmospheric circulation. To do this we simply time average atmosphere and ocean quantities over the 1962-66 period that encompassed the drought and divide the 5-yr period into seasons.

Figure 7 shows the GPCC precipitation, SST, and SLP during the drought. Dry conditions in the greater Catskills region occurred in all seasons with the strongest anomalies in spring as noted by Namias (1966). Winter and summer precipitation anomalies are comparable to those identified in the correlation analysis (Fig. 4) with anomalies focused over eastern North America. In fall dry conditions were more widely spread across the continent. In contrast, the SLP anomalies during the 1960s drought were quite different from those typical of dry periods. While typical dry periods are associated with SLP anomalies centered over eastern North America and the western Atlantic Ocean, the 1960s drought was associated in winter and spring with an extremely strong anomalously low pressure center over the midlatitude Atlantic Ocean with a high pressure anomaly to the north. This was noted by Namias (1966) and represents an extreme negative phase of the North Atlantic Oscillation (NAO) - the seesaw in the pressure and geopotential height anomalies between the subpolar and subtropical Atlantic Oceans. As shown by Hurrell (1995), the early to mid-1960s came at the end of a long-term downward trend of the NAO and at the

\footnotetext{
${ }^{1}$ All of the correlation analyses were repeated using a 6-yr highpass Butterworth filtered version of the greater Catskills precipitation time series and then again using a low-pass version that equaled the original time series minus the high-pass filtered series. The low- and high-pass patterns were essentially the same as those derived using the unfiltered data, indicating that the associations identified are common to different time scales of variability. However, the correlation of increased greater Catskills region precipitation with higher tropical geopotential heights (Fig. 5, MAM and SON seasons), and with positive tropical SST anomalies in SON (Fig. 6d), only appear when the precipitation time series is low-pass filtered. This indicates that these associations are not a consequence of interannual tropical variability but more likely arise from a coincidental correspondence of Catskills region wetting and global warming.
}

beginning of a three-decades-long upward trend that ended in the mid-1990s. Thus the early to mid-1960s were a time of an unusually and persistently negative NAO. This SLP anomaly places anomalous northerly flow over the eastern seaboard of North America.

The SST anomaly during the 1960s drought is characteristic of the negative NAO with warm SST anomalies where the trade winds and midlatitude westerlies (around $60^{\circ} \mathrm{N}$, especially obvious in winter) weaken and cold anomalies under the strong northerlies immediately east of eastern North America. These are all consistent with atmospheric forcing of the ocean and generation of SST anomalies by either surface fluxes and/or anomalous Ekman drift (Bhatt et al. 1998; Seager et al. 2000). The very strong cold anomalies, noted by Namias (1966), in the region of the Gulf Stream and to its north, suggest oceanic gyre and heat transport adjustment to the change in wind forcing (Taylor and Stephens 1998; Visbeck et al. 1998; Seager et al. 2000; Visbeck et al. 2003). The SST anomalies during the drought are consistent with being during the years of a negative NAO before the long-term upward trend of the NAO to the 1990s as shown, for example, in Hurrell (1995) and Seager et al. (2000).

The SST anomalies persist into the summers and falls of the drought while the negative NAO does not. The drought was also present in the summers and falls of the 1962-66 period. The SLP anomaly during the summers and falls has high pressure over the interior continent causing, as in the winters, a northerly component to the flow anomalies over northeastern North America.

Precipitation is favored when the air is ascending. Widespread drying would therefore be expected to be coincident with subsiding motion. Figure 8 plots the 700-hPa vertical pressure velocity during the 1960 s drought for the different seasons together with the 500-hPa height anomalies. First of all, the negative NAO conditions in the winter and spring seen in the SLP data are also seen in the 500-hPa height anomalies. Anomalous subsidence was also present in the greater Catskills region in all the seasons but most noticeably in the winter and spring when the NAO anomaly was strongest. In the spring the anomalous subsidence is coincident with midtropospheric (Fig. 8) and lower tropospheric (Fig. 7) northerly flow. This could be dynamically consistent with a vorticity balance between the advection of planetary vorticity and stretching terms and thermal balance between cooling by northerly advection and warming by compression. However, it must be recognized that winter balances will be more complex than this, likely including eddy fluxes too. During fall there is also weak subsidence in the region under northerly flow to the east of the continental anticyclone. 


\section{2-1966 Precip (land), SST (ocean), and SLP (contours)}

a) DJF

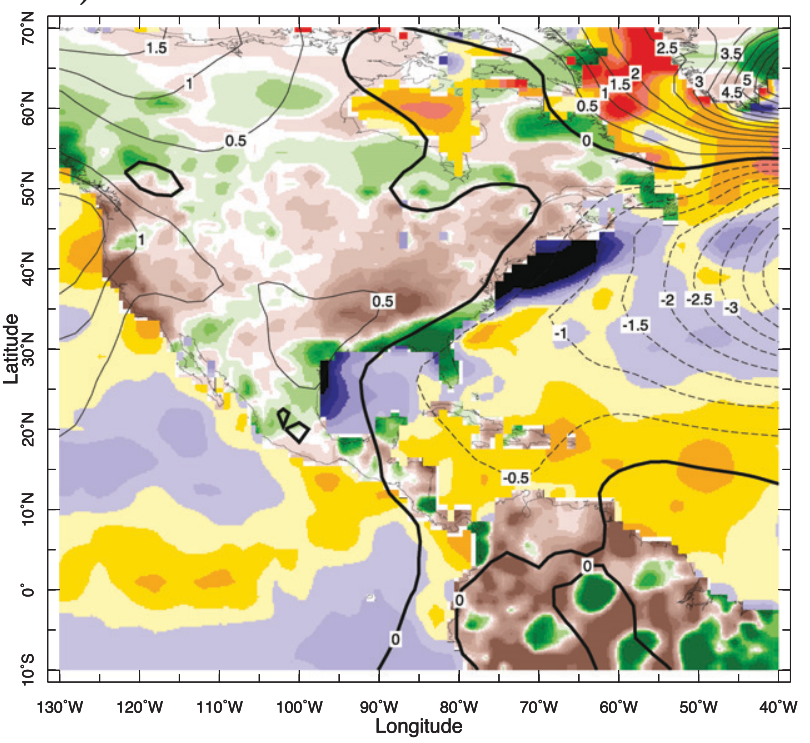

c) JJA

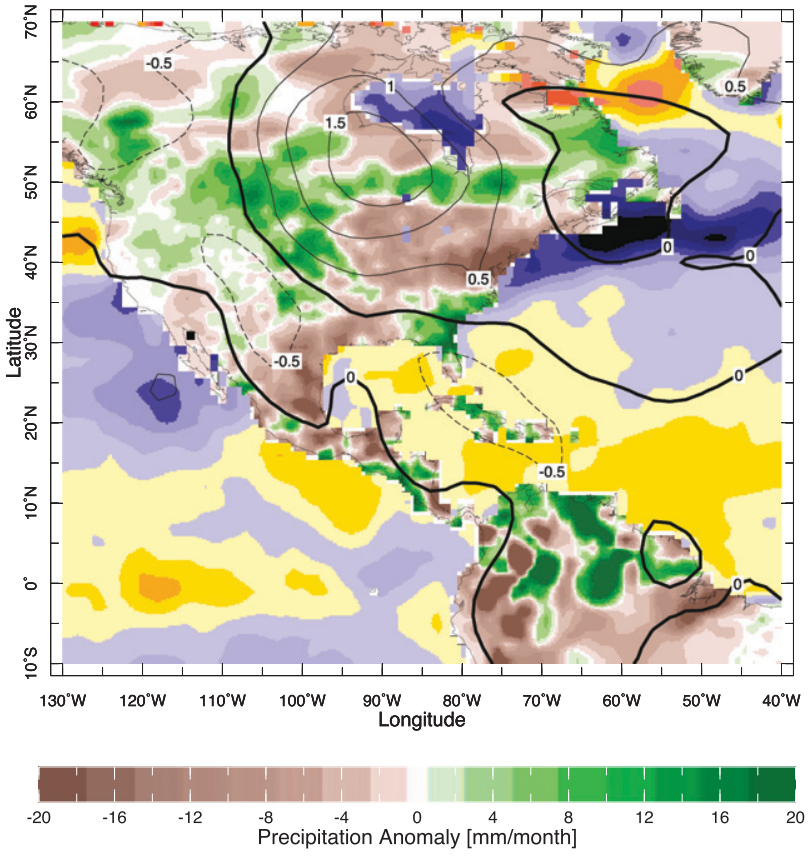

b) MAM

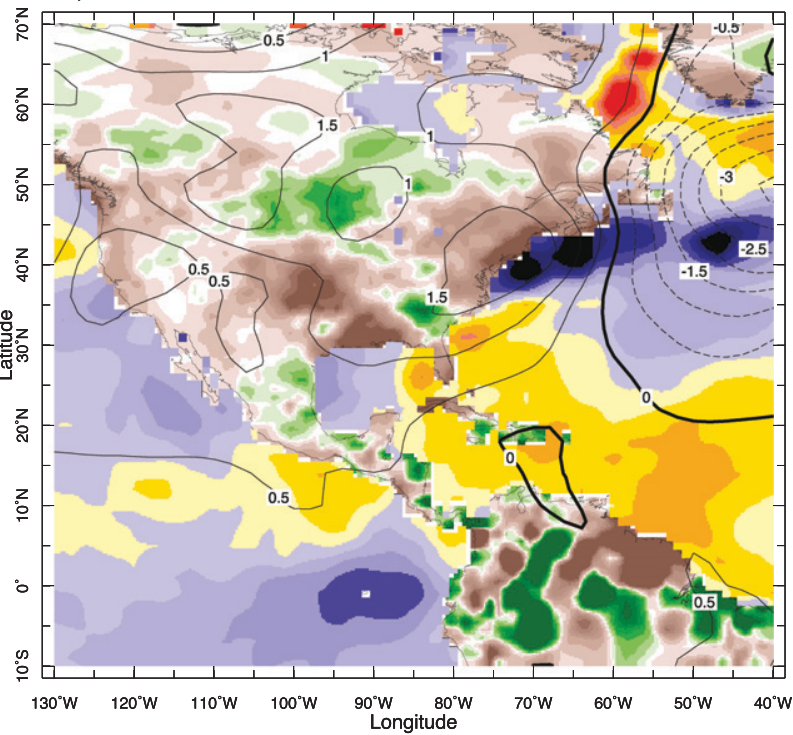

\section{d) $\mathrm{SON}$}
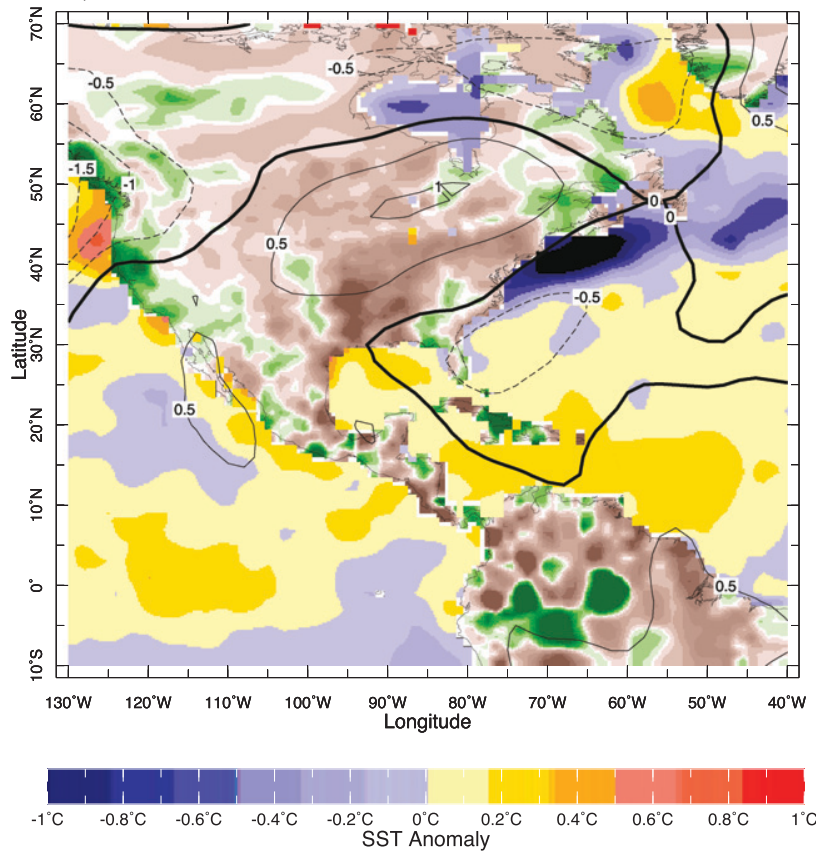

FIG. 7. Anomalies from the 20CR of the SLP (contours, units of hPa), SST (colors over ocean, units of ${ }^{\circ} \mathrm{C}$ ), and GPCC precipitation (colors over land, units of $\mathrm{mm} \mathrm{month}^{-1}$ ) for the (top left) winter (DJF), (top right) spring (MAM), (lower left) summer (JJA), and (lower right) fall (SON) seasons of the 1962-66 drought.

\section{The post-1960s pluvial: Character and atmospheric causes}

The 1960s drought was the most severe the region has experienced since development of the water supply system for New York City and, hence, is of considerable interest. However, since the drought the water supply system has enjoyed the benefits of almost four decades of wetter conditions than earlier in the century. The causes of the wet trend are not known. To examine this transition to a 


\section{2-1966 $700 \mathrm{hPa}$ Vert Vel (color) and $500 \mathrm{hPa}$ Height (contours)}

a) DJF

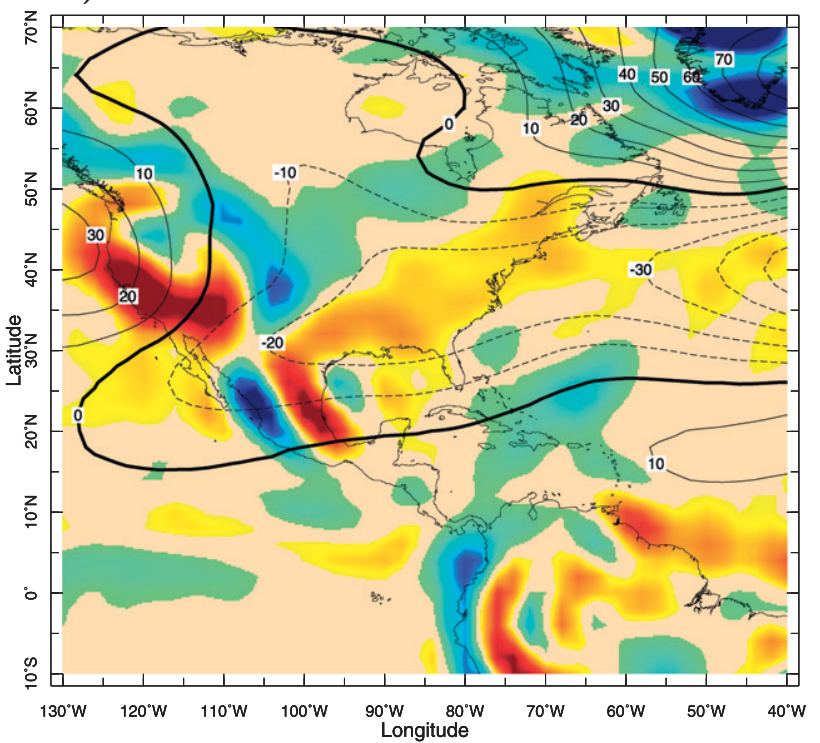

c) JJA

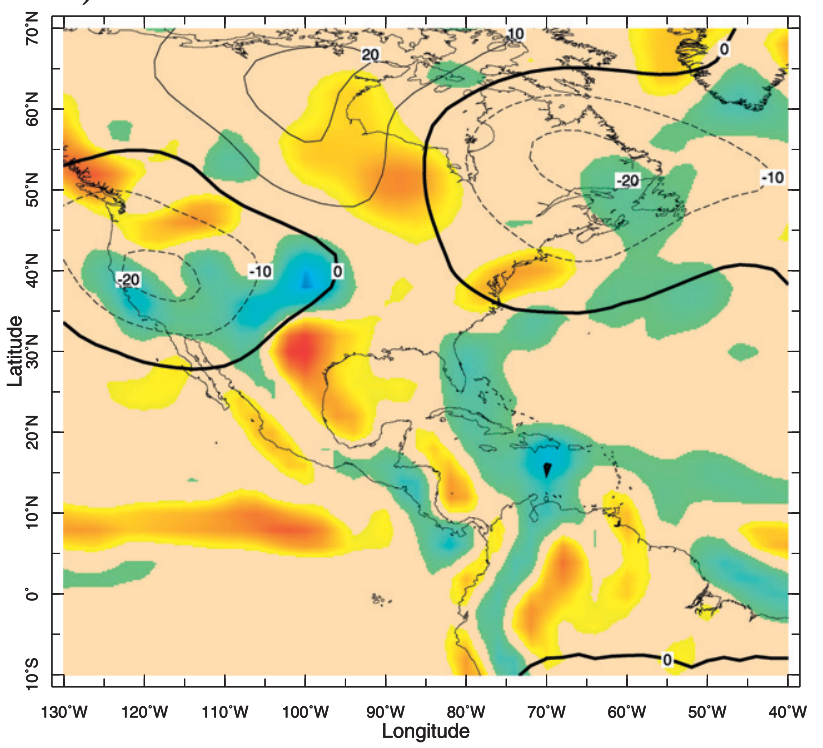

b) MAM

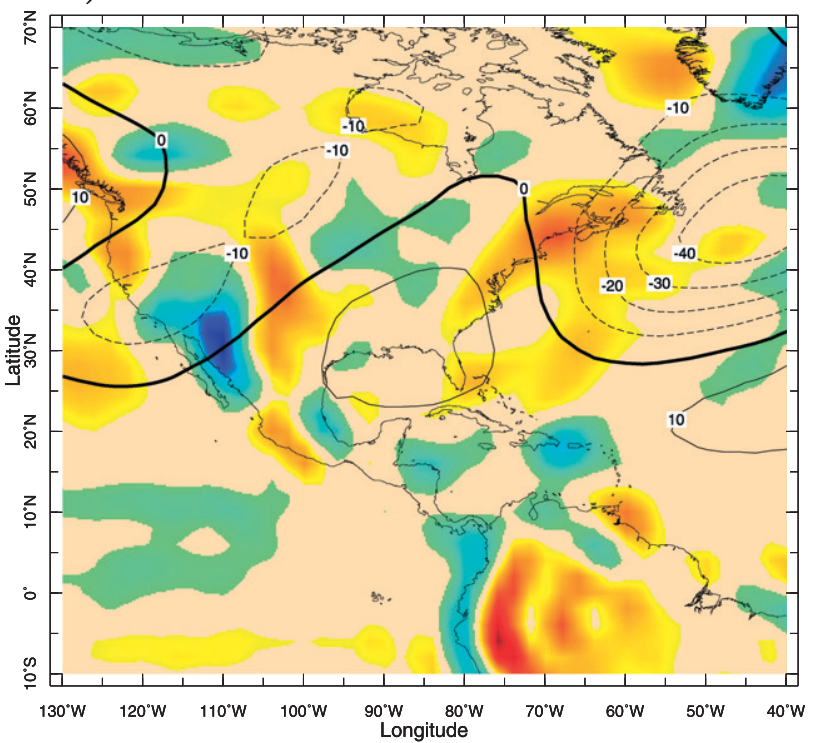

d) $\mathrm{SON}$

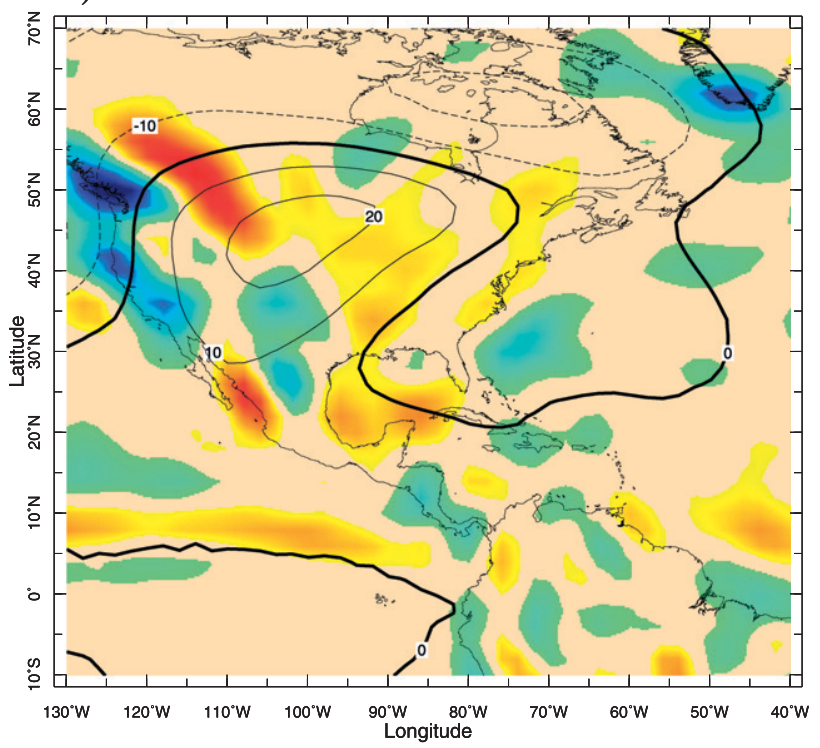

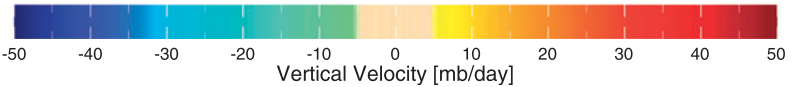

FIG. 8. Anomalies from the $20 \mathrm{CR}$ of the 500 -hPa height (contours, $\mathrm{m}$ ) and vertical pressure velocity (colors, $\mathrm{hPa}^{\mathrm{h}}$ day ${ }^{-1}$ ) for the (top left) winter (DJF), (top right) spring (MAM), (lower left) summer (JJA), and (lower right) fall (SON) seasons of the 1962-66 drought.

wetter climate we look at climate variables averaged over the period from 1972 to 2007 minus the variables averaged over the period up to and including 1971. Since there is a possible link to storm track variations, and since these are not well resolved in reanalyses early in the twentieth century, we use 1949 as the beginning of the earlier period corresponding with the beginning of the NCEP reanalysis.

Figure 9 (top row) shows the change for the period from 1972 to 2007 minus the earlier period (1949-71) in precipitation, SST, and 20CR reanalysis SLP for the 


\section{(1972-2007) - (1949-1971) GPCC Precip and 20CR}

\section{Precip (land), SST (ocean), and SLP (contours)}

a) MAM

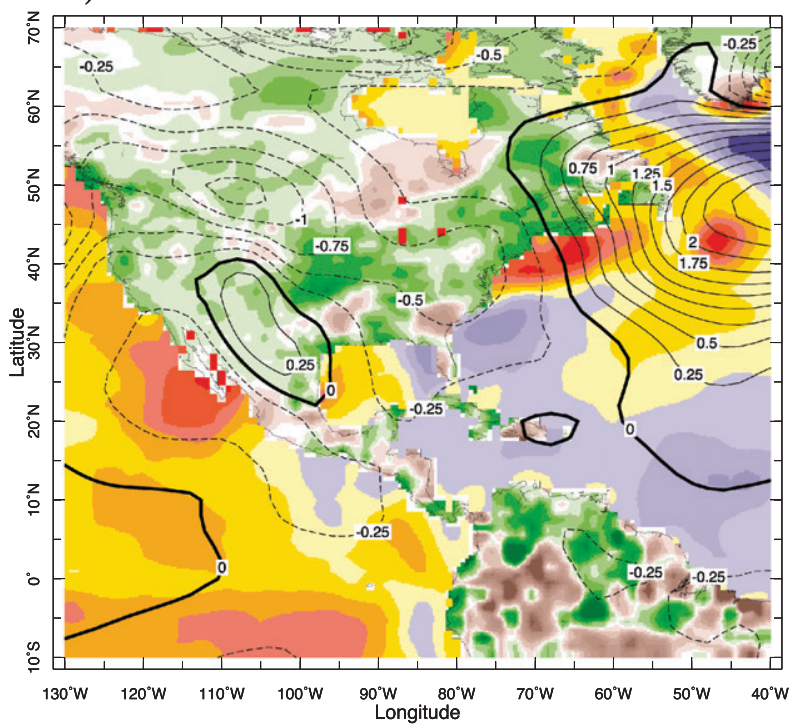

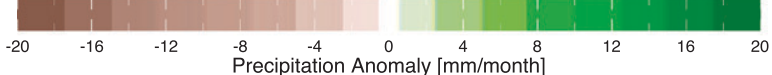

b) $\mathrm{SON}$
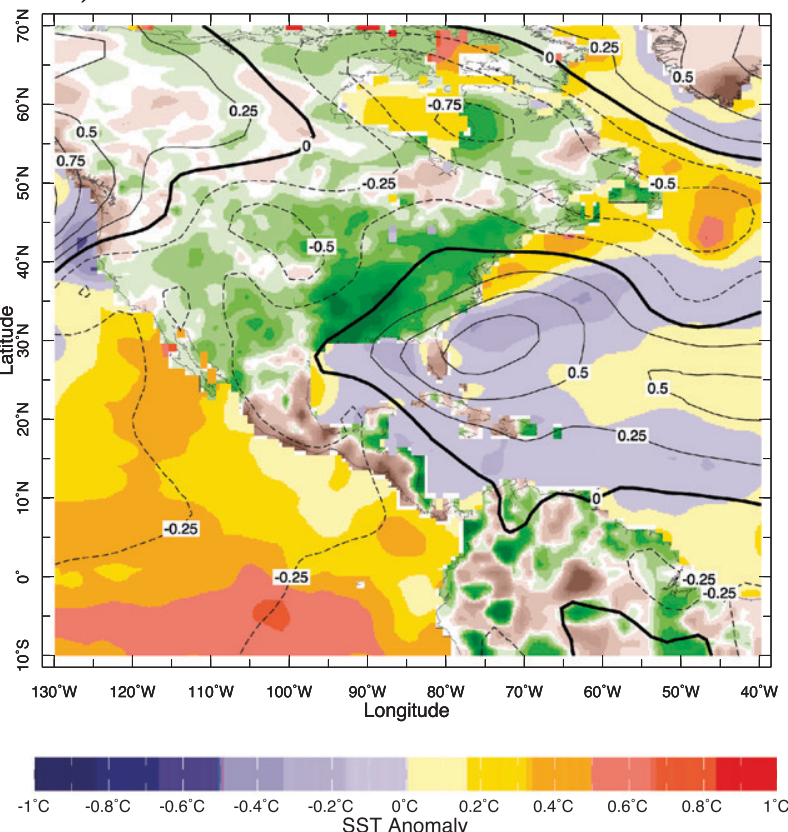

\section{$700 \mathrm{mb}$ Omega (colors) and $500 \mathrm{mb}$ Heights (contours)}

\section{c) MAM}

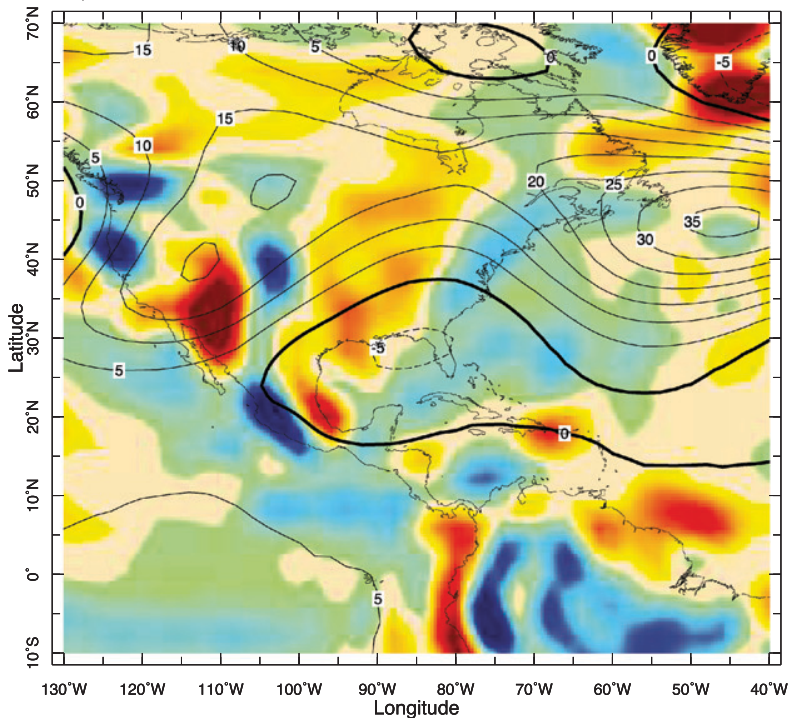

d) SON

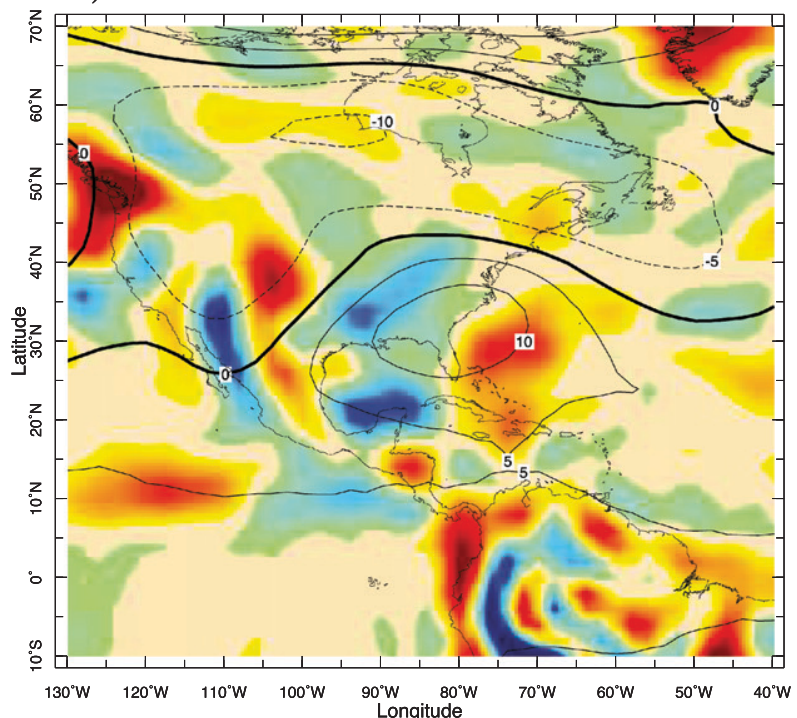

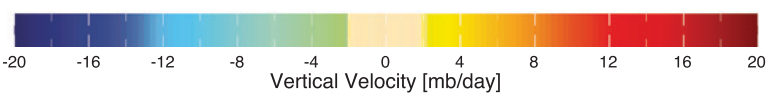

FIG. 9. The difference between the period after 1972 and 1949-71 for (top) GPCC precipitation (colors over land, mm month ${ }^{-1}$ ), SST (colors over ocean, K), and SLP from the 20CR (contours, hPa) and (bottom) 500-hPa heights (contours) and 700-hPa vertical velocity (colors) from the $20 \mathrm{CR}$ for the (left) spring and (right) fall seasons. Units are $\mathrm{mm} \mathrm{day}{ }^{-1}$ for precipitation, $\mathrm{hPa}$ for SLP, ${ }^{\circ} \mathrm{C}$ for SST, $\mathrm{m} \mathrm{for}$ height, and $\mathrm{hPa}$ day $^{-1}$ for vertical pressure velocity. 
spring and fall seasons when the long-term wetting of the greater Catskills region is most obvious. During spring the most striking difference relative to the maps for the 1960s drought is the presence of a strong high pressure anomaly over the Atlantic northeast of northeast North America compared to a low pressure system during the drought. The pluvial SLP anomaly places southeasterly flow anomalies over the greater Catskills region in contrast to northerly flow during the drought. Southeasterly flow anomalies might be expected to favor onshore and ascending moist flow favorable for high-precipitation anomalies. During the fall season of the pluvial there is a high pressure anomaly over the subtropical Atlantic Ocean and general southerly flow anomalies into the south and eastern United States. In this season the positive precipitation anomalies are remarkably widespread across eastern North America from Texas to the Labrador Sea.

The bottom row of Fig. 9 shows the change of the $500-\mathrm{hPa}$ heights and the $700-\mathrm{hPa}$ vertical pressure velocity. The 500-hPa height interdecadal changes are similar in spatial pattern to the changes in the SLP. Of note is that negative vertical pressure velocitiesupward motion-are collocated with lower tropospheric flow with a southerly aspect (and vice versa) and that there is some consistency between the patterns of interdecadal changes in vertical motion and precipitation (even though these are independent datasets).

It is possible that some part of the transition to wetter conditions across the early 1970s is related to the shift from negative (in the 1960s) to positive states of the NAO (e.g., Hurrell 1995; Hurrell et al. 2003; Osborn 2004). Indeed, the transition years for greater Catskills precipitation quite closely match those for the NAO as identified in a coupled analysis of surface atmospheric circulation and Atlantic SSTs (Seager et al. 2000). However, this is unlikely to be the sole cause because 1) as shown in Figs. 5 and 6, greater Catskills region precipitation does not in general correlate with the NAO; 2) there is no prior evidence for a strong NAO connection to precipitation in the northeastern United States (unlike for Europe) (e.g., Hurrell et al. 2003); 3) the NAO trended positive from the 1960s to the mid-1990s but trended negative after that, but greater Catskills precipitation remained high (Figs. 1 and 2); and 4) the NAO itself is most active in the winter season but the wetting trend is strongest in spring and fall. ${ }^{2}$

\footnotetext{
${ }^{2}$ Despite the lack of a strong simultaneous correlation of greater Catskills region precipitation to the NAO, tree ring records in eastern North America have been successfully used to reconstruct the winter NAO over past centuries, although it remains unclear if the trees in this case are responding to precipitation, temperature, or a combination thereof and with a time lag or not (Cook et al. 2002; Cook 2003).
}

However, it is plausible that the wetting trend in the greater Catskills region is linked to another transition in the climate system - one that remains a topic of mystery and controversy. This is the apparent strengthening of the Northern Hemisphere storm tracks in the early 1970s, first noted by Chang and $\mathrm{Fu}$ (2002) on the basis of NCEP reanalysis data. The storm track strengthened in the early 1970s across the North Pacific Ocean, North America, and the North Atlantic Ocean with maximum strengthening from the western Pacific to the eastern Atlantic. The strengthening was later more closely examined by Harnik and Chang (2003), who found that it can also be seen in radiosonde data albeit in a much weaker form than in the reanalysis. They concluded that it is probably genuine and not an artifact of the observing and reporting systems.

Figure 10 shows the interdecadal change in upper tropospheric $250-\mathrm{hPa}$ high-pass filtered transient eddy meridional velocity variance for both the NCEP reanalysis and the 20CR for the MAM and SON seasons. To make this figure daily data from the reanalyses were filtered with a Butterworth filter to isolate variability with 2-10-day time scales. The strengthening across the early 1970s in the NCEP reanalysis is similar to that shown by Chang and $\mathrm{Fu}(2002)$ (who used a different method to identify storm tracks and considered the DJF season). The strengthening in the 20CR is also evident but much weaker. This is very interesting as it provides yet further evidence that the strengthening is real as the 20CR uses only SLP data and excludes the radiosonde data analyzed by Harnik and Chang (2003).

Harnik and Chang (2003) were unable to provide a physical explanation for the strengthening but do note that its timing is similar to the negative to positive NAO transition already discussed. However, we are wary of this association being a full explanation because NAOassociated storm track variations are concentrated over the European sector and are weak over North America (e.g., Rogers 1997). However, any strengthening in the early 1970s would be expected to cause moistening since much of the greater Catskills precipitation is associated with vertical motion within synoptic eddies. To further examine a link between storm systems and precipitation, in Fig. 11 we plot time series of annual means of the greater Catskills precipitation from 1949 on together with $250-\mathrm{hPa}$ high-pass filtered meridional velocity variance in the same region from both the NCEP and 20CR reanalyses. The correlation between the two estimates of the storm track strength above the Catskills is quite good with the interdecadal change clearly being weaker in the 20CR. It is notable how well the precipitation tracks the storm track strength on both the interannual and longer time scales. Clearly the wet shift in the early 1970s and the storm-track strengthening 


\section{(1972-2007) - (1949-1971) 250 hPa V ${ }^{\prime 2}$}

\section{NCEP}

a) MAM

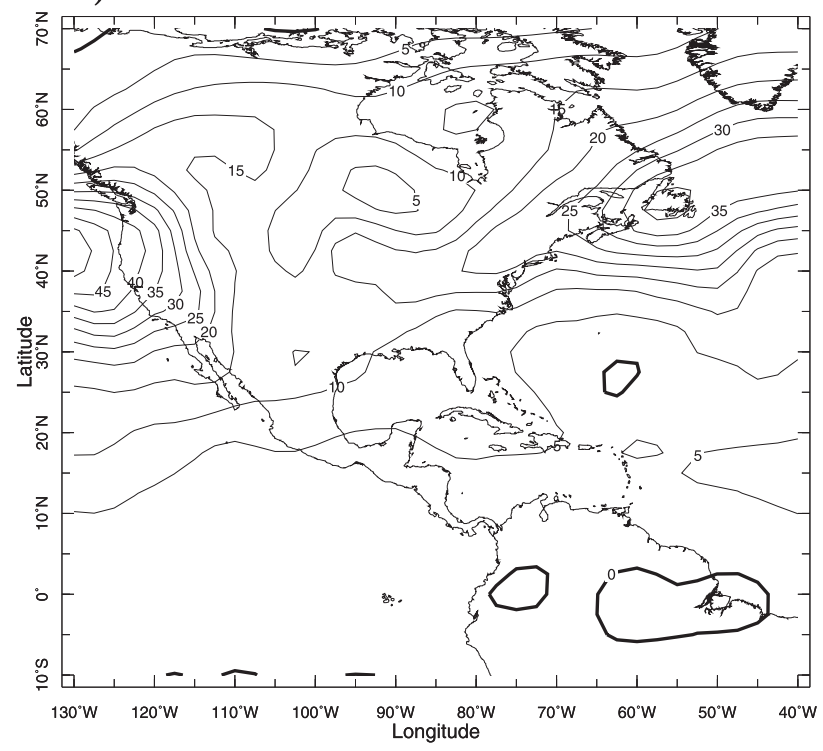

b) $\mathrm{SON}$

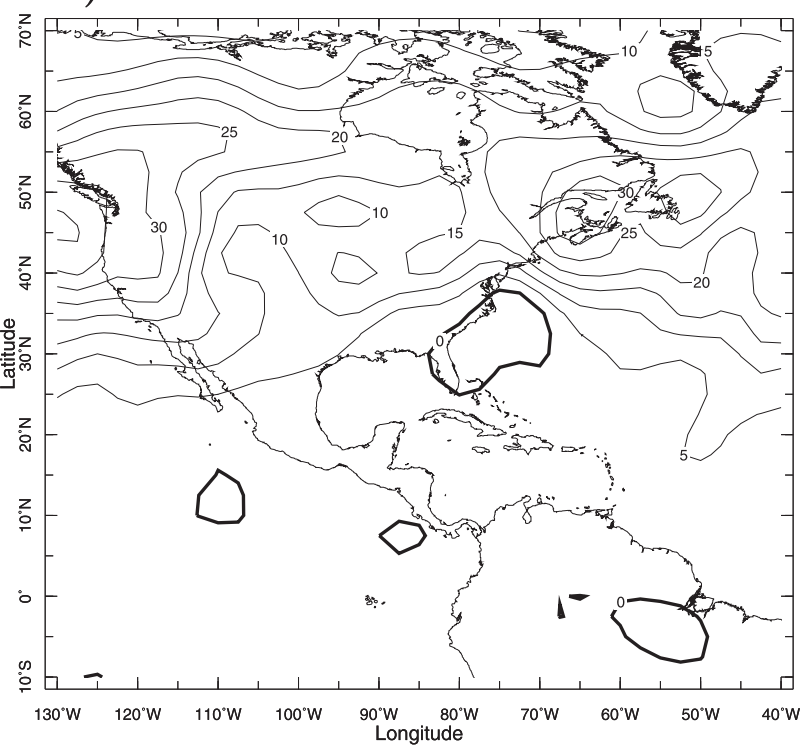

\section{CR}

c) MAM

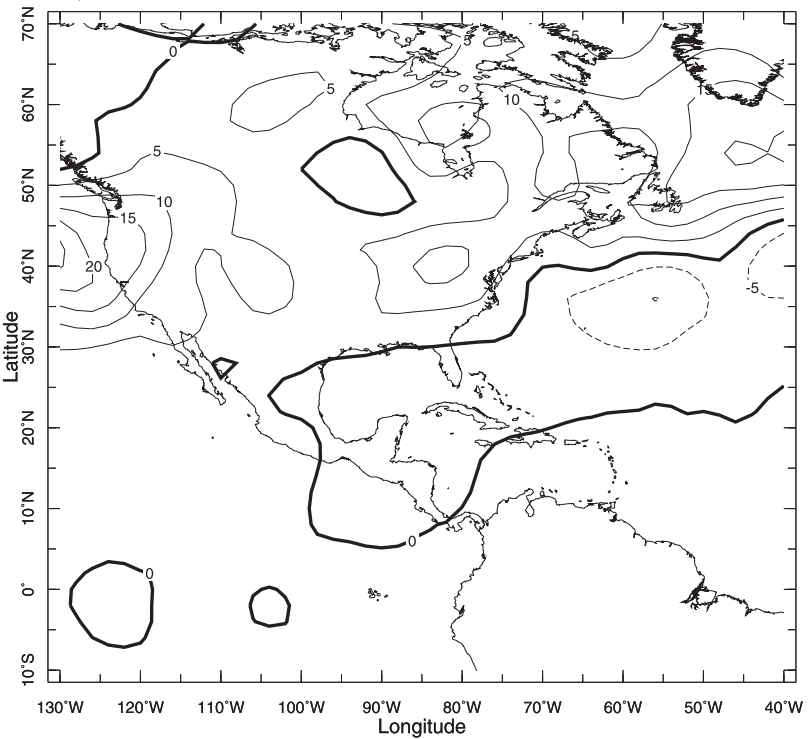

d) $\mathrm{SON}$

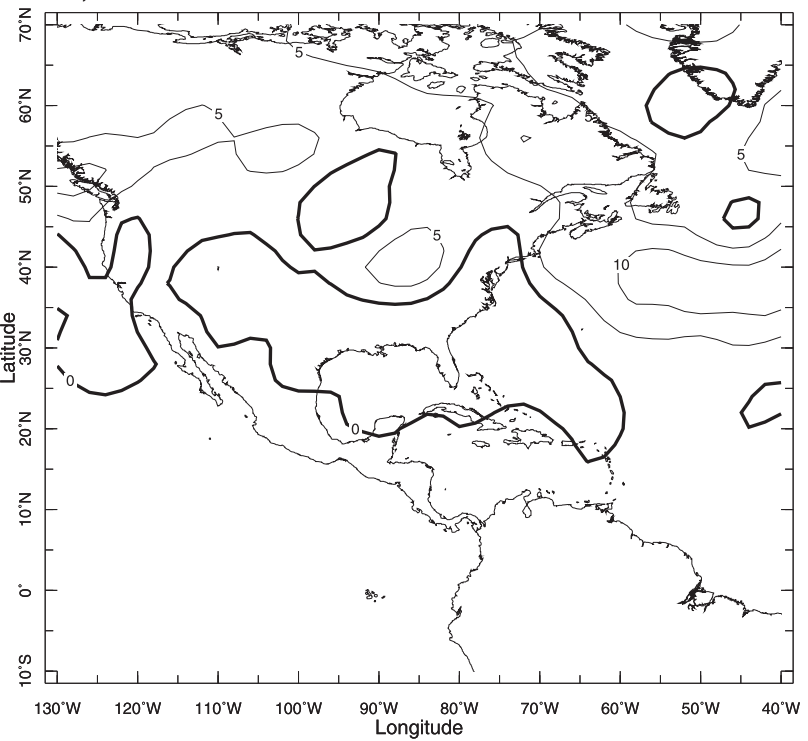

FIG. 10. The difference between the period after 1972 and 1949-71 of the 250-hPa high-pass filtered eddy meridional velocity variance from (top) the NCEP reanalysis and (bottom) the 20CR for the (left) spring and (right) fall seasons. Units are $\mathrm{m}^{2} \mathrm{~s}^{-2}$.

occurred essentially simultaneously. However, the association is strongest in the annual mean data shown here and less clear in individual seasons despite the precipitation data showing the wet transition being most apparent in the spring and fall seasons.

\section{Were the 1960s drought and post-1960s pluvial forced by SST variations?}

We have identified some circulation features associated with the 1960s drought and subsequent pluvial. An 
Catskill Precip (bk solid), 250 hPa V’2 20CR (gry solid), NCEP (dsh)

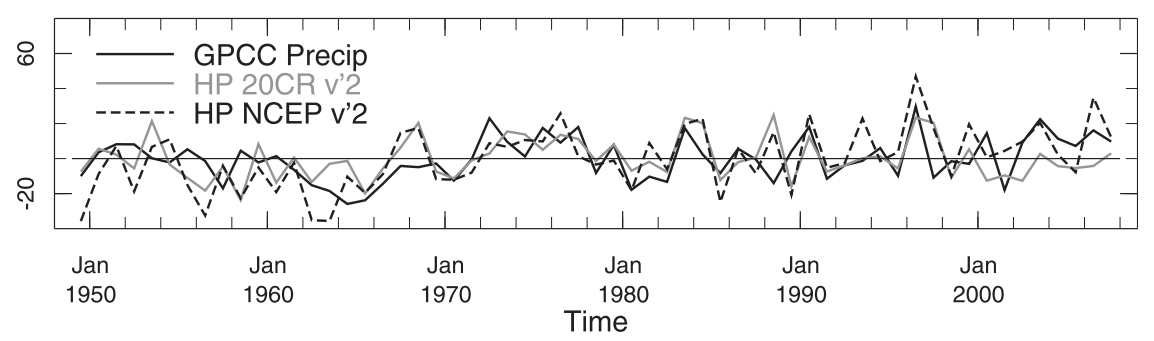

FIG. 11. Time series of annual mean precipitation (black) and 250-hPa high-pass filtered eddy meridional velocity variance from the NCEP (dashed) and 20CR (gray) reanalyses all for the greater Catskills region. Units are $\mathrm{mm} \mathrm{day}^{-1}$ and $\mathrm{m}^{2} \mathrm{~s}^{-2}$.

obvious question is whether these atmospheric circulation features were forced by SST anomalies and, hence, would be predictable if the SST anomalies themselves could be predicted? The way to assess this is to generate an ensemble of atmosphere GCM simulations with different initial conditions but all with the observed history of SSTs imposed as the lower boundary condition. The ensemble mean for a large enough ensemble averages over the uncorrelated atmospheric variability in the ensemble members and isolates the common, SSTforced, component. The extent to which the SST-forced ensemble mean tracks the observed precipitation is a measure of the extent to which the observed precipitation was forced by SST variations as opposed to generated by internal atmospheric variability. For example, atmosphere GCM simulations of the 1856 to recent period show that a significant share of precipitation variability in southwestern North America and the Great Plains was forced by SST variation with the tropical Pacific and Atlantic Oceans taking prime responsibility (Seager et al. 2005b, 2009), which is in agreement with similar studies (Schubert et al. 2004b,a). Namias (1966) suggested that western North Atlantic SST anomalies could have caused the 1960s drought while Barlow et al. (2001) suggested it was caused by North Pacific SST anomalies. Next we test these claims.

Figure 12 shows the comparison of the modeled and observed precipitation in the greater Catskills region for the simulations with the NCAR models that include the entire twentieth century. The observed precipitation is the solid line and the ensemble mean is the dashed line, while the plus and minus 2 standard deviations spread of the 16-member ensemble is shown by shading. The correlation coefficient between the observed precipitation and the ensemble mean is indicated at the left. None of these three models produce the 1960s drought and none have a transition to a wetter climate in the last few decades of the century. Further, the observed and modeled precipitation are uncorrelated. (While it is not clear from the figure, we have checked the $\mathrm{CCM} 3$ results for any link of greater Catskills region precipitation to SSTs and found that it actually has a strong correlation to tropical Pacific SSTs even though the amplitude of the connection is weak. In the ensemble mean of CCM3, El Niño conditions force wet conditions in the Catskills as part of a general wetting of southern and central North America. In the eastern United States this modeled El Niño-precipitation correlation extends far north of that observed and creates a spurious connection since, as shown in Fig. 6, observed precipitation in the greater Catskills region has no such connection.)

Figure 13 shows the comparison for the other three models that just simulated the post-1950 period. None of these produced the 1960s drought and, while the wetting is harder to discern with only a 50-yr period to examine, they too do not seem to reproduce this. As with the NCAR models, modeled and observed greater Catskills precipitation are uncorrelated. The models thus are in agreement that precipitation in the greater Catskills region, including the drought and the wetting trend, are not forced by variations in SSTs anywhere in the World Ocean. If the models are correct then the drought and wetting trend must have arisen from internal atmospheric processes (and including possible land surface feedbacks). This is in stark contrast to the situation in the Southwest, Great Plains, and Mexico, where the model simulations indicate that up to a quarter of the observed precipitation histories were forced by SST variations (Seager et al. 2005b, 2009). However, it is consistent with the observational analyses of precipitation patterns and circulation that were suggestive of a local control from internally generated atmospheric circulation anomalies, perhaps including for the 1960s drought, the NAO.

Although the atmosphere models imply that the drought and pluvial were not forced by SST variations it is worth asking whether the model can ever produce droughts similar to the observed 1960s drought. To examine this we analyzed the individual CCM3 ensemble 

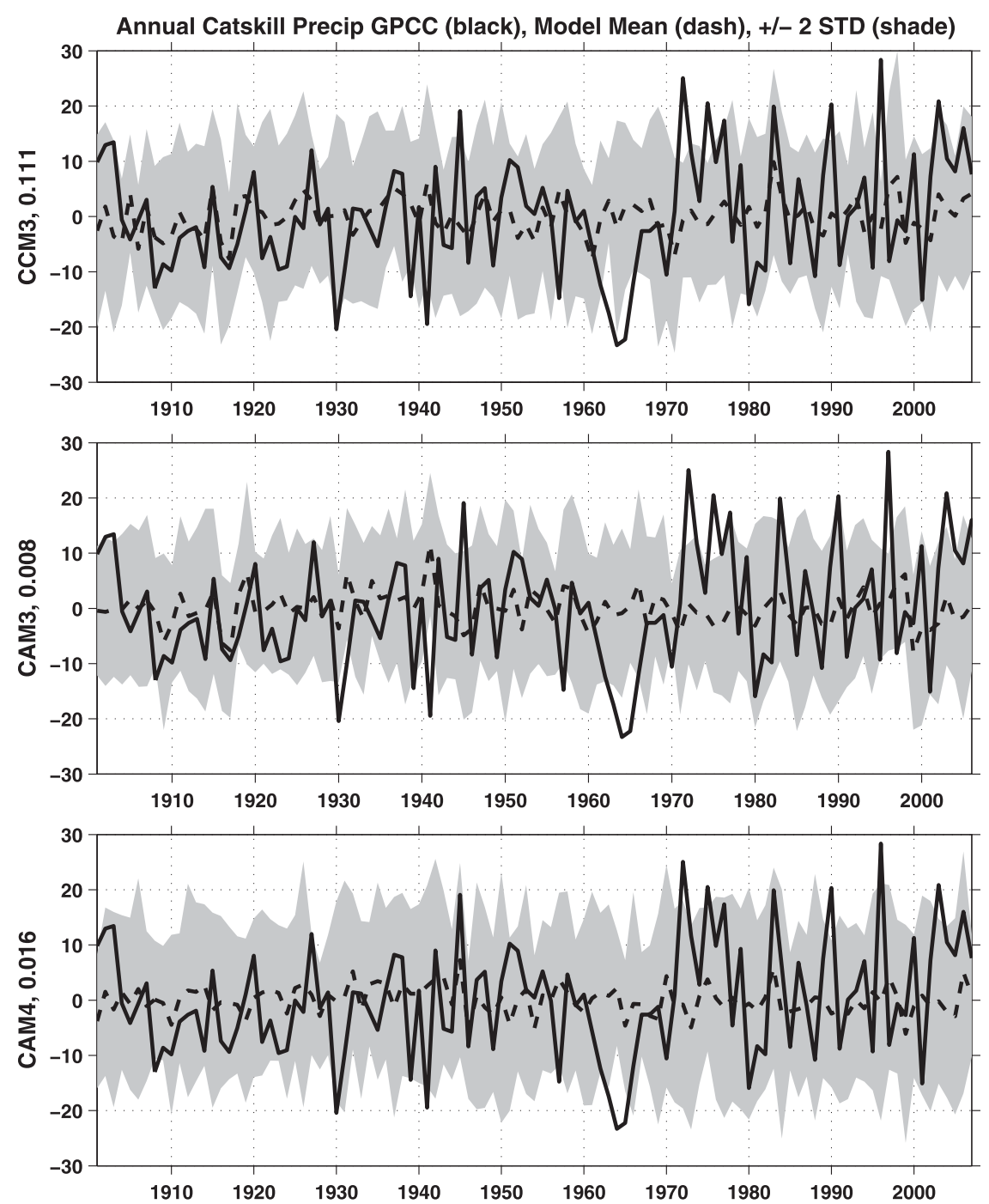

FIG. 12. The observed annual mean precipitation for the greater Catskills region (soild) and the mean of 16-member ensembles of atmosphere GCMs forced by global observed SSTs (dashed) together with the 2 standard deviation spread of the ensemble (shading about the dashed line) for the (top) CCM3, (middle) CAM3, and (bottom) CAM4 for the 1901-2007 period. Correlations coefficients of the observed and model ensemble mean are shown on the vertical axis. Units are mm month ${ }^{-1}$.

members after subtracting the ensemble mean. This removes the common SST-forced component of the precipitation variability and leaves that generated by internal atmospheric variability. These model histories of internal atmosphere variability were examined and contained several cases of multiyear and multiseason droughts in the greater Catskills region of a severity equal to that of the 1960s drought. The circulation anomalies were examined for each of these. While some had a negative NAO state like during the 1960s drought others did not and, in general, it appears as if the CCM3 model is capable of producing droughts as severe as the observed one via a variety of internally generated atmospheric circulation anomalies. Thus there would be no canonical atmospheric circulation pattern for severe drought in the greater Catskills region.

\section{Is the transition to wetter conditions in the greater Catskills caused by anthropogenic climate change?}

It does not seem as if SST variations were responsible for the 1960s drought in that none of seven models produce the drought when forced with observed SSTs. 

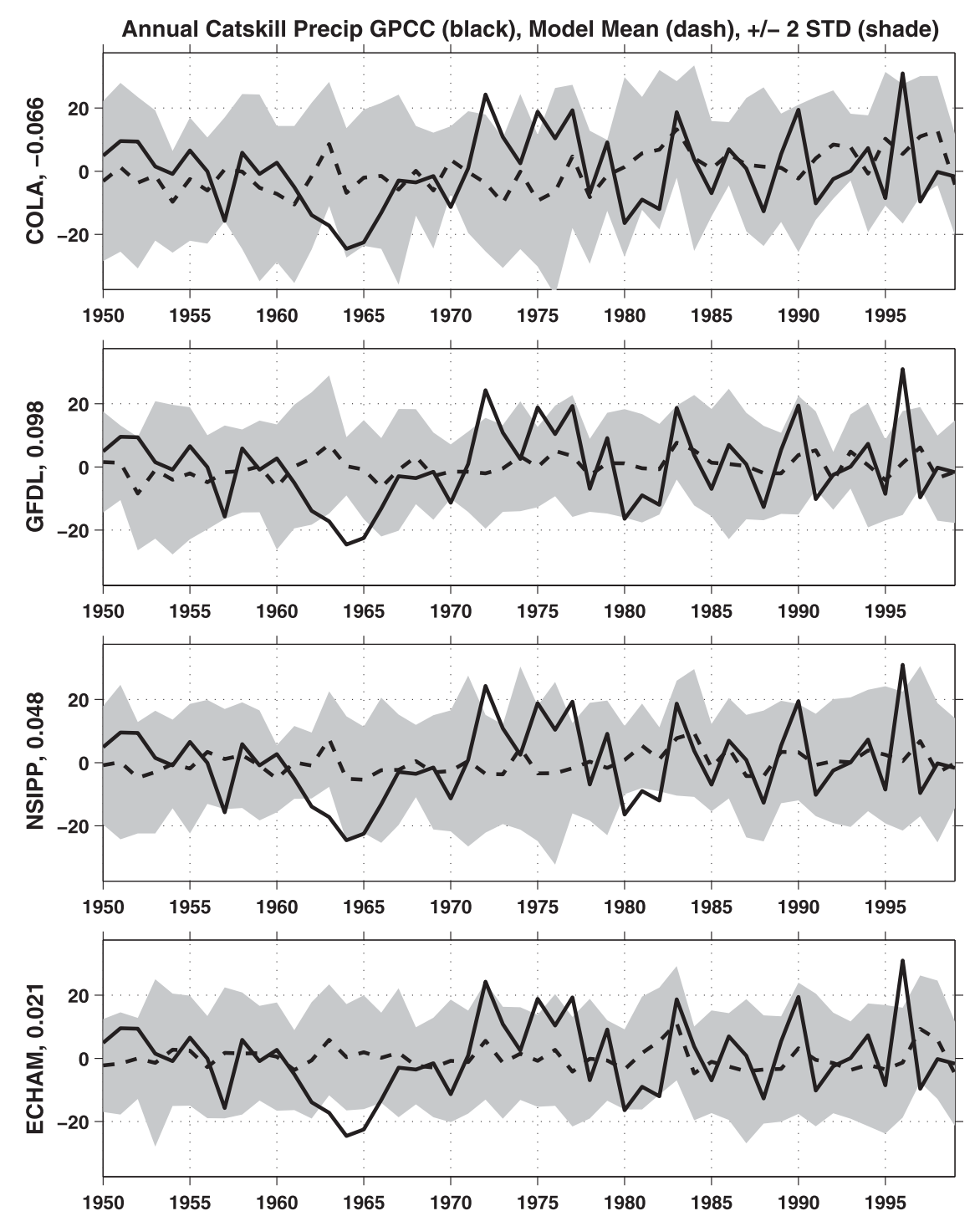

FIG. 13. As in Fig. 9 but for four ensembles of atmosphere GCMs and the 1950-2000 period only for the (top) COLA, (upper middle) GFDL AM2.1, (lower middle) NSIPP, and (bottom) ECHAM4.5 models. Units are mm month ${ }^{-1}$.

In addition, SST variations apparently did not cause the long-term wetting of the greater Catskills regions. If SST changes were not responsible could the wetting have arisen as a direct response to increasing concentrations of greenhouse gases, changes in aerosols, and other anthropogenic alterations to the climate system? To assess that possibility we analyzed the twentieth-century precipitation history in the 24 coupled atmosphere-ocean models that participated in the IPCC AR4/CMIP3. Figure 14 shows the ensemble mean of the 24 models' annual precipitation for 1900-2000 averaged over the greater Catskills region as well as the 2 standard deviation spread of the distribution of the modeled precipitation around the ensemble mean. With only a few exceptions the observed seasonal means of precipitation fall within the range of the modeled precipitations. However, the models have essentially no precipitation trend in the region in any season. Hence the models provide no support for the idea that the observed wetting could have been caused by anthropogenic alterations to the climate system.

At this point it is worth asking if the observed shift to a wetter spring and fall climate in the greater Catskills region is within the range of what climate models can generate. To do this we examined 107-yr-long trends by season in the SST-forced atmosphere model simulation using the same globally forced ensemble discussed in section 7 as well as another 16-member ensemble forced 

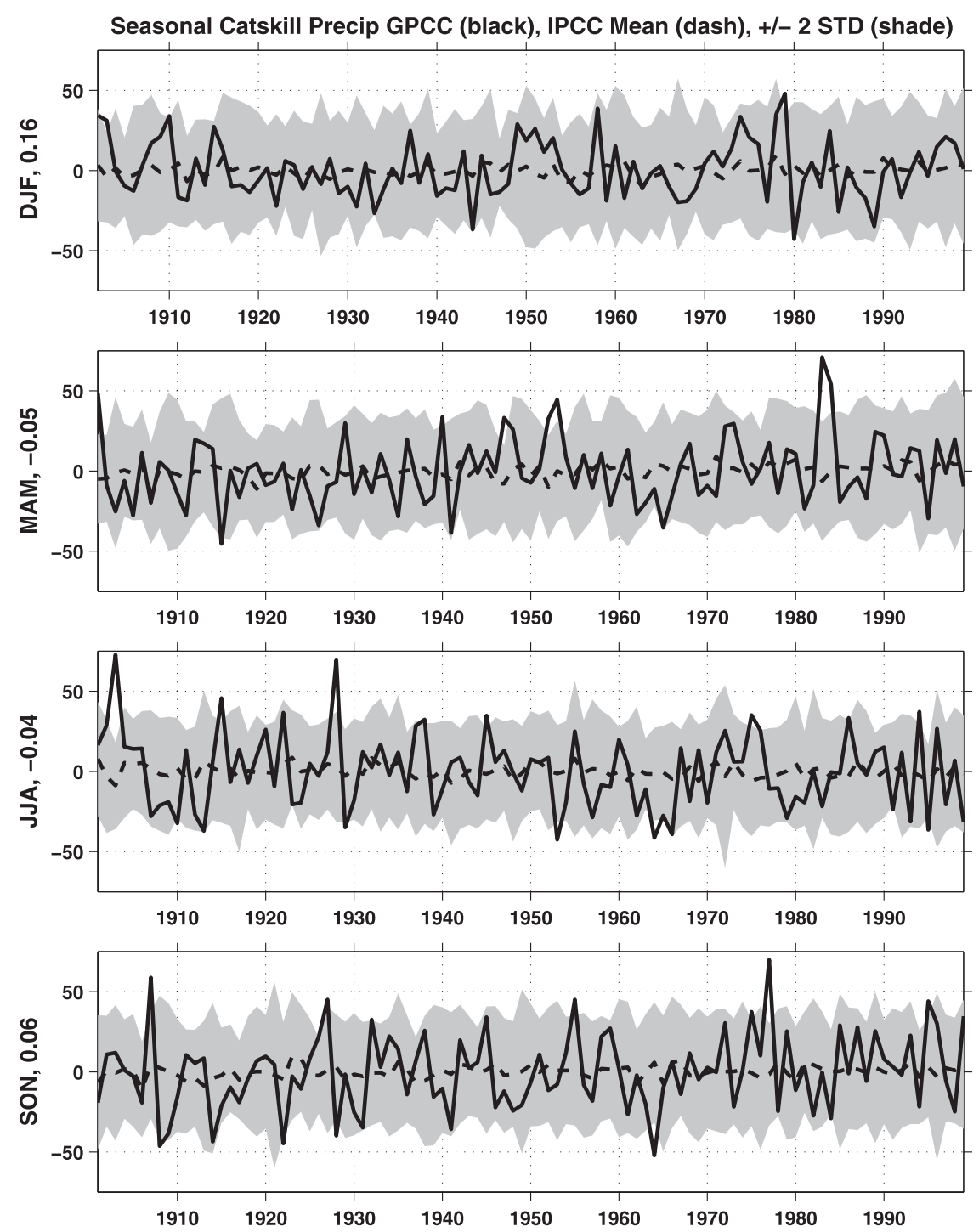

FIG. 14. The observed precipitation (solid line) plotted with the mean (dashed line) and 2 standard deviation spread of the 24-member model ensemble (shading) precipitation from IPCC AR4 for the 1900-2000 period in the greater Catskills region for the four seasons. Correlation coefficients between the observed and model mean are shown at left. Units are $\mathrm{mm}$ month $^{-1}$.

by only tropical Pacific SSTs with a mixed layer ocean elsewhere (see Seager et al. 2005b). To minimize overlap we computed 107-yr-long trends beginning in 1856, 1878, and 1900. With two 16-member ensembles this makes for 96 model trends. The observed precipitation trend in all seasons, including the wetting in MAM, fall comfortably within the distribution of model trends except for during SON when the observed trend is twice the size of the largest model trend (of either sign). This may be influenced by the fact that the observed mean SON precipitation in the region is $50 \%$ larger than that in the model.
We then computed 1900-99 trends from all 76 model runs in the IPCC AR4/CMIP3 ensemble. After scaling by a factor of 1.07 to compare to the observed 1901-2007 trend we once again found that the observed trend was comfortably within the model distribution for the DJF, MAM, and June-August (JJA) seasons. During SON just one of the 76 model runs had a trend in excess of the observed trend. (This was a run of the ECHAM5 model; the other three runs of the same model, like for the multimodel ensemble as whole, do not produce a wetting trend. The multimodel ensemble mean climatological SON precipitation in the region is only slightly 
less than observed.) Hence, the models provide some support for the notion that the observed wetting trend could have arisen from internal climate variability but it is clearly at the very limit of model behavior. More work needs to be done to determine if this is a more general phenomena indicating that model variability on multidecadal time scales is too weak. The causes of the late twentieth-century pluvial must for now, alas, remain a mystery.

\section{Conclusions}

New York City and 9 million consumers depend for their water on reliable precipitation in a network of reservoirs in the Croton River watershed and the Catskill Mountains with the great majority of the water coming from the latter. The last reservoirs were completed in the 1960s. Reductions in water use have prevented serious water shortages from occurring frequently in recent decades. However, precipitation in the Catskills regions is highly variable on interannual-to-multidecadal time scales. In particular the decades since the completion of the water supply system have been wetter than earlier periods in the twentieth century, which will have eased pressures on providing adequate water for the city. Before this wet period-or pluvial-there was a severe multiyear drought in the early to mid-1960s that stands out as the worst the region has experienced in the instrumental period. The causes and dynamics of the 1960s drought and subsequent pluvial were analyzed here with the following conclusions.

- The 1960s drought is a common feature in rain gauge records across the greater Catskills region and was a year-round event. The drought impacted most of the northeastern United States with particular strength in the spring season.

- Interannual precipitation anomalies in the greater Catskills region are spatially correlated with precipitation anomalies across just eastern North America and are related to wavelike patterns of atmospheric circulation variability that are confined to the Pacific-North America-Atlantic sector of the midlatitudes without connection to the tropics. Wet conditions correspond to midtropospheric southerly flow within these wave patterns. The associated SST anomalies in the Atlantic Ocean have patterns suggesting they were forced by the atmospheric circulation anomalies (with possible land surface feedbacks). These results suggest that interannual precipitation variability in the Catskills region is dominated by internal atmospheric variability. This is in contrast to western North America and the Great Plains where much work has made clear that tropical Pacific and Atlantic SST anomalies force as much as a quarter of the interannual variance of precipitation.

- The early to mid-1960s drought did not accord very closely to the typical atmospheric circulation pattern associated with interannual dry years. Instead, in the winter and spring seasons, it was associated with a basin-scale low pressure anomaly over the midlatitude North Atlantic Ocean. This was related to the negative NAO typical of these years. The low placed northerly and descending flow over eastern North America, especially during the spring season, that would be expected to suppress precipitation. During the summer and fall seasons of the drought a highpressure anomaly was centered northwest of the Catskills region and, once more, flow anomalies had a northerly component and associated subsidence though much less striking than in the other seasons. The spring circulation features were previously remarked upon by Namias (1966) and, in further agreement, we note the very cold SST anomalies year round throughout the drought in the Gulf Stream region. Unlike Namias (1966) we believe the SST anomalies were not causal of the drought but forced by the northerly flow anomalies as in Seager et al. (2000).

- The postdrought pluvial primarily occurred in the spring and fall seasons when it was part of a general wetting trend of eastern North America. During the spring seasons, and in contrast to the situation during the drought, there was an anomalous highpressure system over the midlatitude Atlantic Ocean and southeasterly and ascending flow that would be expected to enhance precipitation. During the fall seasons the region of wetting corresponded to southwesterly and ascending flow anomalies around a highpressure anomaly centered over the southeast United States.

- All seven atmosphere models forced by historical SSTs failed to simulate the 1960s drought or the subsequent pluvial. This strongly suggests that these aspects of precipitation history did not arise as a response to slowly varying ocean conditions (unlike droughts in the southwest and plains that typically are ocean forced). Analysis of 24 models participating in IPCC AR4 did not show a significant wetting trend in the greater Catskills region over the last century. Consequently, the preponderance of evidence suggests that both the 1960s drought and the subsequent pluvial arose from internal atmospheric dynamics. This is consistent with analysis showing that, not just for the drought and the pluvial, but, in general, precipitation anomalies in the region are caused by internal atmospheric variability. 
- There is tantalizing evidence indicating that the early 1970s transition to a wetter climate was caused by a strengthening locally, and from the Pacific to the Atlantic, of the Northern Hemisphere storm tracks. This strengthening appears in the NCEP reanalysis and radiosonde data as previously shown (Harnik and Chang 2003) and also in the Twentieth Century Reanalysis, which assimilates only SLP data. There is also some correspondence between precipitation and local storm-track strength variations on the interannual time scale. The causes of the storm-track strengthening are unknown but it should not be assumed that it is simply related in a one-to-one manner with the NAO trend.

It is unfortunate that the detailed anomalies of the atmospheric moisture budget associated with the drought and pluvial cannot be determined because the NCEPNCAR reanalysis data are not sufficiently accurate. It is sobering that even in a well-observed region such as the United States and within recent decades our observing system is insufficient to fully characterize and determine the causes of such socially important hydroclimate events.

In conclusion, the precipitation history in the Catskills Mountains region of the New York City watershed, including such dramatic events as the early to mid-1960s drought and the subsequent pluvial, were likely caused by atmospheric variability and not by SST anomalies. If so, they are likely not predictable on time scales longer than that of extended range weather forecasting (although the possibility that soil moisture feedbacks may extend the range of prediction should not be excluded). There is also no model-based evidence that the wetting trend was caused by anthropogenic climate change. This means that, first, it cannot be assumed that the wet climate of recent decades will continue and that, instead, drier conditions more typical of the last century could return and, second, a severe drought like that of the 1960s could again happen at any time and with no warning and with no ability to predict either its onset or its continuation. The New York City water supply system needs to be managed accordingly.

Acknowledgments. This work was supported by NOAA Grants NA08OAR4320912 and NA10OAR4320137 and NSF Grant ATM-08-04107. SJ was supported by an Earth Institute at Columbia University undergraduate research fellowship. We thank Naomi Naik and Virginia DiBlasiMorris for help with the figures and analysis and Ed Cook and Rosanne D'Arrigo for useful discussions. The comments and advice of the Global Decadal Hydroclimate $(\mathrm{GloDecH})$ group at Lamont and Columbia were essential to the progress of this work. The comments of three reviewers are also appreciated.

\section{REFERENCES}

Barlow, M., S. Nigam, and E. H. Berberry, 2001: ENSO, Pacific decadal variability, and U.S. summertime precipitation, drought, and stream flow. J. Climate, 14, 2105-2128.

Bhatt, U. S., M. A. Alexander, D. S. Battisti, D. D. Houghton, and L. M. Keller, 1998: Atmosphere-ocean interaction in the North Atlantic: Near-surface variability. J. Climate, 11, 16151632 .

Bone, K., G. Pollara, and P. Deppe, 2006: Water-Works: The Architecture and Engineering of the New York City Water Supply. Monacelli Press, 268 pp.

Burns, D. A., J. Klaus, and M. R. McHale, 2007: Recent climate trends and implications for water resources in the Catskill Mountain region, New York, USA. J. Hydrol., 336, 155170.

Cayan, D., 1992a: Latent and sensible heat flux anomalies over the northern oceans: Driving the sea surface temperature. J. Phys. Oceanogr., 22, 859-881.

_ 1992b: Latent and sensible heat flux anomalies over the northern oceans: The connection to monthly atmospheric circulation. J. Climate, 5, 354-369.

Chang, E. K. M., and Y. Fu, 2002: Interdecadal variations in Northern Hemisphere winter storm track intensity. J. Climate, 15, 642-658.

Compo, G., and Coauthors, 2011: The Twentieth Century Reanalysis project. Quart. J. Roy. Meteor. Soc., 137, 1-28.

Cook, E. R., 2003: Multi-proxy reconstructions of the North Atlantic Oscillation (NAO) index: A critical review and a new well-verified winter NAO index reconstruction back to AD 1400. The North Atlantic Oscillation: Climatic Significance and Environmental Impact, J. W. Hurrell et al., Eds., Amer. Geophys. Union, 63-80.

, and G. C. Jacoby, 1977: Tree-ring-drought relationships in the Hudson Valley, New York. Science, 198, 399-401.

—, D. M. Meko, D. W. Stahle, and M. K. Cleaveland, 1999: Drought reconstructions for the continental United States. J. Climate, 12, 1145-1162.

—, R. D. D'Arrigo, and M. E. Mann, 2002: A well-verified, multiproxy reconstruction of the winter North Atlantic Oscillation Index since A.D. 1400. J. Climate, 15, 1754-1764.

Degaetano, A. T., 1999: A temporal comparision of drought impacts and responses in the New York City metropolitan area. Climatic Change, 42, 539-560.

Delworth, T., and Coauthors, 2006: GFDL's CM2 coupled climate models. Part I: Formulation and simulation characteristics. J. Climate, 19, 643-674.

Groisman, P. Ya., R. W. Knight, D. R. Easterling, T. R. Karl, G. C. Hegerl, and V. N. Razuvaev, 2005: Trends in intense precipitation in the climate record. J. Climate, 18, 1326-1350.

Harnik, N., and E. K. M. Chang, 2003: Storm track variations as seen in radiosonde observations and reanalysis data. J. Climate, 16, 480-495.

Hayhoe, K., and Coauthors, 2007: Past and future changes in climate and hydrological indicators in the US Northeast. Climate Dyn., 28, 381-407.

Houghton, J. T., G. J. Jenkins, and J. J. Ephraums, Eds., 2007: Climate Change: The IPCC Scientific Assessment. Cambridge University Press, 365 pp. 
Huntington, T. G., G. A. Hodgkins, B. D. Keim, and R. W. Dudley, 2004: Changes in the proportion of precipitation occurring as snow in New England (1949-2000). J. Climate, 17, 2626-2636.

Hurrell, J. W., 1995: Decadal trends in the North Atlantic Oscillation: Regional temperatures and precipitation. Science, 269, 676-679.

—, Y. Kushnir, G. Ottersen, and M. Visbeck, 2003: An overview of the North Atlantic Oscillation. The North Atlantic Oscillation: Climatic Significance and Environmental Impact, J. W. Hurrell et al., Eds., Amer. Geophys. Union, 1-35.

Kalnay, E., and Coauthors, 1996: The NCEP/NCAR 40-Year Reanalysis Project. Bull. Amer. Meteor. Soc., 77, 437-471.

Kirtman, B., Y. Fan, and E. K. Schneider, 2002: The COLA global coupled and anomaly coupled ocean-atmosphere GCM. J. Climate, 15, 2301-2320.

Kistler, R., and Coauthors, 2001: The NCEP-NCAR 50-Year Reanalysis: Monthly means CD-ROM and documentation. Bull. Amer. Meteor. Soc., 82, 247-267.

Lyon, B., N. Christie-Blick, and Y. Gluzberg, 2005: Water shortages, development, and drought in Rockland County, New York. J. Water Res. Assoc., 41, 1457-1469.

Meehl, G., C. Covey, T. Delworth, M. Latif, B. McAvaney, J. F. B. Mitchell, R. J. Stouffer, and K. E. Taylor, 2007: The WCRP CMIP3 multimodel dataset: A new era in climate change research. Bull. Amer. Meteor. Soc., 88, 1383-1394.

Namias, J., 1966: Nature and possible causes of the northeastern United States drought during 1962-65. Mon. Wea. Rev., 94, 543-554.

, 1983: Some causes of United States drought. J. Climate Appl. Meteor., 22, 30-39.

Osborn, T. J., 2004: Simulating the winter North Atlantic Oscillation: The roles of internal variability and greenhouse gas forcing. Climate Dyn., 22, 605-623.

Pires, M., 2004: Watershed protection for a world city: The case of New York. Land Use Policy, 21, 161-175.

Postel, S. L., and B. H. Thompson, 2005: Watershed protection: Capturing the benefits of nature's water supply services. Nat. Resour. Forum, 29, 98-108.

Rayner, N. A., D. E. Parker, E. B. Horton, C. K. Folland, L. V. Alexander, D. P. Rowell, E. C. Kent, and A. Kaplan, 2003: Global analyses of sea surface temperature, sea ice, and night marine air temperature since the late nineteenth century. J. Geophys. Res., 108, 4407, doi:10.1029/2002JD002670.

Roeckner, E. K., and Coauthors, 1996: The atmospheric general circulation model ECHAM-4: Model description and simulation of present day climate. Max-Planck-Institut für Meteorologie Tech. Rep. 218, 90 pp.

Rogers, J., 1997: North Atlantic storm track variability and its association to the North Atlantic Oscillation and climate variability of northern Europe. J. Climate, 10, 1635-1645.
Rosenzweig, C., D. C. Major, K. Demong, C. Stanton, R. Horton, and M. Stults, 2007: Managing climate change risks in New York City's water system: Assessment and adaptation planning. Mitigation Adapt. Strategies Global Change, 12, 13911409.

Schneider, U., T. Fuchs, A. Meyer-Christoffer, and B. Rudolf, 2008: Global precipitation analysis products of the GPCC. Global Precipitation Climatology Centre Tech. Rep., 12 pp.

Schubert, S. D., M. J. Suarez, P. J. Pegion, R. D. Koster, and J. T. Bacmeister, 2004a: Causes of long-term drought in the United States Great Plains. J. Climate, 17, 485-503.

,,,---- , and,$- 2004 \mathrm{~b}$ : On the cause of the 1930s dust bowl. Science, 303, 1855-1859.

Seager, R., 2007: The turn-of-the-century North American drought: Dynamics, global context, and prior analogues. J. Climate, 20, 5527-5552.

_ , Y. Kushnir, M. Visbeck, N. Naik, J. Miller, G. Krahmann, and H. Cullen, 2000: Causes of Atlantic Ocean climate variability between 1958 and 1998. J. Climate, 13, 2845-2862.

—, N. Harnik, W. A. Robinson, Y. Kushnir, M. Ting, H. P. Huang, and J. Velez, 2005a: Mechanisms of ENSO-forcing of hemispherically symmetric precipitation variability. Quart. J. Roy. Meteor. Soc., 131, 1501-1527.

_ , Y. Kushnir, C. Herweijer, N. Naik, and J. Velez, 2005b: Modeling of tropical forcing of persistent droughts and pluvials over western North America: 1856-2000. J. Climate, 18, 4068-4091.

_- and Coauthors, 2009: Mexican drought: An observational, modeling and tree ring study of variability and climate change. Atmósfera, 22, 1-31.

Taylor, A. H., and J. A. Stephens, 1998: The North Atlantic Oscillation and the latitude of the Gulf Stream. Tellus, $\mathbf{5 0 A}, 134$ 142.

Trenberth, K., 1984: Some effects of the finite sample size and persistence on meteorological statistics. Part I: Autocorrelations. Mon. Wea. Rev., 112, 2359-2368.

Trombulak, S. C., and R. Wolfson, 2004: Twentieth-century climate change in New England and New York, USA. Geophys. Res. Lett., 31, L19202, doi:10.1029/2004GL020574.

Turner, R. K., and G. C. Daily, 2008: The ecosystem services framework and natural capital conservation. Environ. Resour. Econ., 39, 25-35.

Visbeck, M., H. Cullen, G. Krahmann, and N. Naik, 1998: An ocean model's response to North Atlantic Oscillation-like wind forcing. Geophys. Res. Lett., 25, 4521-4524.

_, E. Chassignet, R. Curry, T. Delworth, B. Dickson, and G. Krahmann, 2003: The ocean's response to North Atlantic Oscillation variability. The North Atlantic Oscillation: Climatic Significance and Environmental Impact, J. W. Hurrell et al., Eds., Amer. Geophys. Union, 113-146. 